\title{
Evolution and Diversity of Plant Cell Walls: From Algae to Flowering Plants
}

\author{
Zoë A. Popper, ${ }^{1}$ Gurvan Michel, ${ }^{3,4}$ Cécile Hervé, ${ }^{3,4}$ \\ David S. Domozych, ${ }^{5}$ William G.T. Willats, ${ }^{6}$ \\ Maria G. Tuohy, ${ }^{2}$ Bernard Kloareg, ${ }^{3,4}$ \\ and Dagmar B. Stengel ${ }^{1}$
}

\footnotetext{
${ }^{1}$ Botany and Plant Science, and ${ }^{2}$ Molecular Glycotechnology Group, Biochemistry, School of Natural Sciences, National University of Ireland, Galway, Ireland; email: zoe.popper@nuigalway.ie

${ }^{3}$ CNRS and ${ }^{4}$ UPMC University Paris 6, UMR 7139 Marine Plants and Biomolecules, Station Biologique de Roscoff, F-29682 Roscoff, Bretagne, France

${ }^{5}$ Department of Biology and Skidmore Microscopy Imaging Center, Skidmore College, Saratoga Springs, New York 12866

${ }^{6}$ Department of Plant Biology and Biochemistry, Faculty of Life Sciences, University of Copenhagen, Bülowsvej, 17-1870 Frederiksberg, Denmark
}

Annu. Rev. Plant Biol. 2011. 62:567-90

First published online as a Review in Advance on February 22, 2011

The Annual Review of Plant Biology is online at plant.annualreviews.org

This article's doi:

10.1146/annurev-arplant-042110-103809

Copyright (c) 2011 by Annual Reviews. All rights reserved

$1543-5008 / 11 / 0602-0567 \$ 20.00$

\section{Keywords}

xyloglucan, mannan, arabinogalactan proteins, genome, environment, multicellularity

\begin{abstract}
All photosynthetic multicellular Eukaryotes, including land plants and algae, have cells that are surrounded by a dynamic, complex, carbohydrate-rich cell wall. The cell wall exerts considerable biological and biomechanical control over individual cells and organisms, thus playing a key role in their environmental interactions. This has resulted in compositional variation that is dependent on developmental stage, cell type, and season. Further variation is evident that has a phylogenetic basis. Plants and algae have a complex phylogenetic history, including acquisition of genes responsible for carbohydrate synthesis and modification through a series of primary (leading to red algae, green algae, and land plants) and secondary (generating brown algae, diatoms, and dinoflagellates) endosymbiotic events. Therefore, organisms that have the shared features of photosynthesis and possession of a cell wall do not form a monophyletic group. Yet they contain some common wall components that can be explained increasingly by genetic and biochemical evidence.
\end{abstract}




\section{Contents}

INTRODUCTION .............. 568

WALL COMPOSITION OF

PLANTS AND ALGAE ......... 570

MULTICELLULARITY

AND BODY PLAN ............ 571

Generation of Multicellularity ..... 571

Differentiation and Cell-Wall

Diversity ................. 573

Cell-Cell Communication......... 579

Unicellularity................. 579

TERRESTRIALIZATION,

VASCULARIZATION, AND

DIVERSIFICATION ........... 580

Aquatic Habitats ................ 580

Terrestrialization .............. 581

Innate Immunity .............. 582

CONCLUSIONS AND KEY

PROBLEMS 582

Charophycean green algae (CGA, Charophyceae): a monophyletic group comprising predominantly freshwater green algae that share several features of land plants and include the closest extant ancestors of land plants and their relatives

Archaeplastida: a monophyletic supergroup comprising the Glaucophyta, the Rhodophyta (red algae), and the Chloroplastida (green algae and land plants)

\section{INTRODUCTION}

Significant progress has been made in the past 40 years in our understanding of the structure, synthesis, and function of plant cell walls. Much of the research effort has been directed toward investigating the cell walls of only a few species, mostly flowering plants (angiosperms) of economic importance. However, more recently, potentially driven by the awareness that "small modifications in their chemistry can have profound effects on the multifarious functions cell walls perform" (88), there has been substantial interest in the wall biochemistry of early diverging plants and the charophycean green algae (CGA) (17, 30, 38, 39, 101, 103, 123, $124,136)$. Gaining a complete understanding of plant cell-wall evolution might be achieved only by more closely investigating the origins of cell walls. Niklas (88) highlighted that cell walls have "deep roots in the tree of life." Land plants evolved from CGA, which conquered freshwater habitats after their separation from ancient chlorophyte green algae $(10,69)$.
The land plants, CGA, and chlorophytes represent only part of the Archaeplastida, a monophyletic eukaryotic group that also comprises red and glaucophyte algae (4). As is the case with all plastid-containing Eukaryotes, the emergence of the Archaeplastida is linked tightly to their photosynthetic history. The Archaeplastida are thought to have originated through a single shared event, primary endosymbiosis with a cyanobacterium, over 1,500 Mya. The chlorophyll $c$-containing algae, which include brown algae, evolved soon after through secondary endosymbiosis with a red alga (95). Two scenarios are suggested for their endosymbiotic history: ( $a$ ) a single endosymbiotic event followed by loss of the rhodobionts in Rhizaria, and subsequent gain of chlorobionts in the Chlorarchniophyta [the chromalveolate hypothesis $(19,54)]$, and $(b)$ the increasingly more favored scenario in which multiple secondary endosymbiotic events occurred $(9,82$, 126) (Figure 1).

Both the Archaeplastida and brown algae share two distinctive features: the presence of a complex, dynamic, carbohydrate-rich cell wall, which, to some extent, is dependent on the second feature, the ability to photosynthesize. Stebbins (125) suggested the "adaptive importance of cell wall differentiation," and the significance of the cell wall to each lineage is highly evident: both have independently evolved multicellularity (20) and (along with the wall-less animals) are among the most extensively researched, ecologically and economically important organisms on the planet. Although the two lineages do not form a natural group, and their cell walls have evolved independently (88), it is likely that at least some of their wall components have a shared ancestry (103).

Bioinformatics is beginning to resolve the gene transfers associated with the origin of photosynthetic lineages, in particular those that occurred during the primary endosymbiotic event that led to the emergence of the Archaeplastida. It has been deduced that $18 \%$ of the nuclear genes in the Arabidopsis genome are potentially of cyanobacterial origin (77). Although cyanobacterial cell walls, 


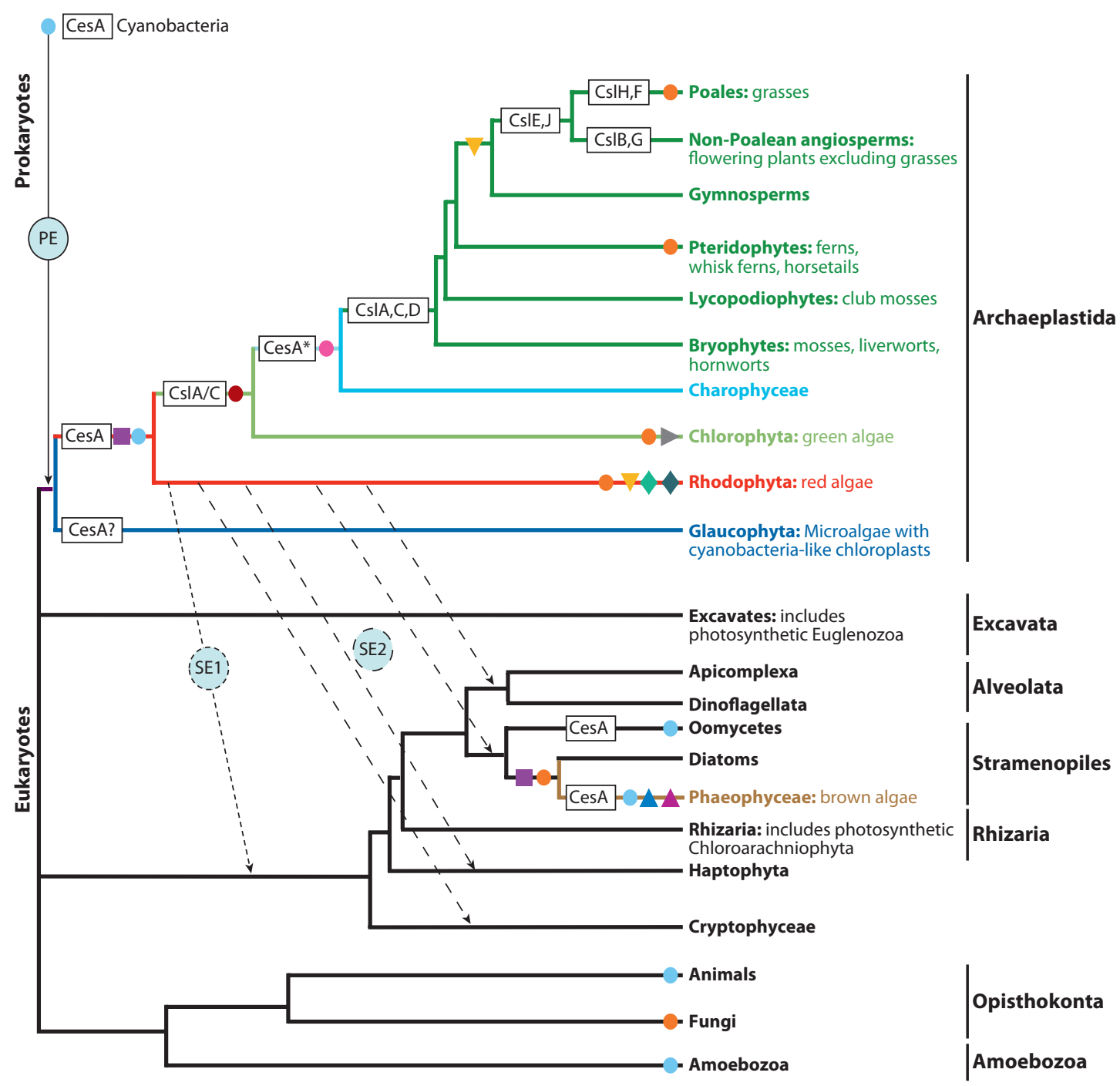

\begin{tabular}{|c|c|c|c|c|c|}
\hline \multicolumn{6}{|c|}{ Key } \\
\hline - & Cellulose & $\bullet$ & Pectins & 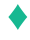 & Agars \\
\hline - & $(1-3),(1-4)-\beta$-D-glucan & - & Xyloglucan & $\Delta$ & Carrageenans \\
\hline$\nabla$ & $\begin{array}{l}\text { Lignin and lignin-like } \\
\text { compounds }\end{array}$ & - & Arabinogalactan proteins & $\Delta$ & Fucoidans \\
\hline
\end{tabular}

Figure 1

Simplified Eukaryote phylogeny highlighting the occurrence of major wall components. The identification of specific wall components within lineages $(1,4,43,69)$ is symbolized as shown in the key. Genes responsible for cellulose and hemicellulose biosynthesis (144) are indicated in boxes: $\operatorname{Ces} A^{*}$ represents members of the cellulose synthase family whose proteins assemble into rosette terminal complexes, Ces $A$ is the ancestral form of cellulose synthases, and CslA/C is a single gene that is most similar to the land plant CslA and CslC gene families. The arrows indicate the origin of the plastids: PE (solid arrow), primary endosymbiosis; SE1 (dotted arrow), secondary endosymbiosis scenario 1 in which the Alveolata, Cryptophyceae, Haptophyta, and Stramenopiles originate from a common ancestor, which acquired its plastids by a secondary endosymbiosis event with a red alga (19), which Rhizaria subsequently lost and the Chlorarchniophyta regained (54); SE2 (dashed arrows), secondary endosymbiosis scenario 2, separate acquisitions of rhodobionts $(9,82,126)$. 
Algae: unifying term for the collection of distinct photosynthetic lineages that evolved independently and can live in terrestrial environments, but predominantly inhabit aquatic habitats

\section{Primary}

endosymbiosis: the uptake and retention of a cyanobacterium by a heterotrophic eukaryotic cell

Brown algae (Phaeophyceae): a group containing multicellular algae with chlorophyll $a / c-$ containing plastids that emerged 200 Mya, through secondary endosymbiosis with a red alga consisting of a peptidoglycan-polysaccharidelipopolysaccharide matrix, fundamentally are different from the polysaccharide-rich cell walls of plants and algae, it has been proposed that genes present in the primary endosymbiont may have provided the basis for plant and algal cell-wall biosynthesis (103). Current genomic evidence indicates that at least $10 \%$ of the genome of flowering plants is associated with wall biosynthesis and metabolism (129). This situation likely is mirrored in the algae, thereby making the resolution of cell-wall structure and biology pivotal to understanding algal and plant evolution.

Intensified research on the cell-wall biochemistry of plants and algae has brought recognition that wall modification has been extensive, enabling adaptation to different evolutionary pressures $(17,38,39,101,102,123$, $124,132,136)$, and considerable attention has focused recently on the evolution of cell-wall components $(99,103,118,123)$. In this review, we discuss several major events in the evolution of plant and algal lineages, including multicellularity, terrestrialization, and vascularization,

\section{METHODS FOR INVESTIGATING CELL-WALL BIODIVERSITY}

Detailed analysis of cell-wall components from many species, tissues, and developmental stages is essential to recognize fully their diversity in plants and algae $(103,123)$. Several key methods commonly employed for wall analyses has been compiled and described $(37,100)$. Considering the vast number of plant and algal species, high-throughput screening methods, including Comprehensive Microarray Polymer Profiling (CoMPP) (84), OLIigosaccharide Mass Profiling (OLIMP) (91), and Fouriertransform infrared microspectroscopy (85), can be developed further to provide an initial step preceding more extensive characterization $(103,123)$. Immunocytochemistry using monoclonal antibodies and carbohydrate-binding modules (49) is also an extremely powerful technique as it enables in situ localization of wall components and, combined with specific wall treatments (76) or advanced microscopy such as electron tomography (92) and livecell imaging (44), additionally can indicate interactions between wall components in their native environment. and the involvement of the cell wall in these processes.

\section{WALL COMPOSITION OF PLANTS AND ALGAE}

Plant and algal cell-wall components are subject to intense research, not least because they are of high economic value within the paper, food, and fiber industries; have projected future use for biofuels, nutraceuticals, and pharmaceuticals; and are of ecological importance (88). Thus, a body of expertise facilitating the investigation of wall composition and knowledge regarding the occurrence of cell-wall components has been garnered (see the sidebar Methods for Investigating Cell-Wall Biodiversity). Although this was centered mostly on crop species of flowering plants and algae (e.g., Laminaria and Gracilaria), sufficient evidence was available to suggest that diversity in cellwall composition between taxa has its foundation in the evolution of specific lineages. Investigators have built on this data in the past $\sim 10$ years, and several reviews give a detailed outline of the occurrence of specific wall components in major plant and algal taxa $(57,88,93$, 99, 103, 123, 124) (Figure 2). We summarize the major trends seen in the polysaccharides in Table 1 and the genes that control their synthesis in Table 2 and Figure 1. In brief, the CGA have cell walls that are closely similar in composition to the land plants (Table 2), which descended from them, and thus appear to be at a pivotal position in wall evolution, making them ideal models for land-plant cell-wall research [see the sidebar Penium margaritaceum (Zygnematophyta) as a Model Organism]. Within this monophyletic group (Figures 3 and 4), both major and subtle changes in wall composition have occurred and may indicate specific evolutionary pressures. However, these changes occurred (Figures $\mathbf{1}$ and $\mathbf{3}$ ) in a background that was homogenous at its commencement. This is in stark contrast to the situation in algae, which, far from being a monophyletic group, consist of several lineages with complex evolutionary histories (see above). However, it is possible to 
discern major changes in cell-wall composition between algal lineages and between plant and algal lineages (Table $\mathbf{2}$ and Figures $\mathbf{1}$ and $\mathbf{3}$ ).

Examination at the genomic level also makes it possible to discern the evolution and acquisition of the required cell-wall biosynthetic machinery (83) (Table 2 and Figure 1). Many classes of polysaccharides within the algal lineages appear to be highly diverse in terms of their degree of sulfation, esterification, and molecular weight and conformation of sugar residue $(57,93)$. Some of these differences vary according to species (57) but could be difficult to reconcile with specific evolutionary theories as they probably involve regulation of biosynthetic networks rather than the presence or absence of specific genes; further genomic information and elucidation of biochemical pathways in algal cell walls are essential for confirmation.

\section{MULTICELLULARITY AND BODY PLAN}

\section{Generation of Multicellularity}

The transition from unicellular to simple multicellular organization occurred independently in at least 25 lineages (41). However, complex multicellular organisms evolved only in six eukaryotic groups: animals, fungi, brown algae, red algae, green algae, and plants. Thus the evolution of multicellular complexity appears to be a rare, difficult transition (41). Interestingly, Niklas \& Kutschera (89) asserted that land plant multicellularity, together with specific features of their life cycle, is retained from their last common algal ancestors, the CGA, either because they represent a developmental constraint (87) or because they facilitated survival in a terrestrial environment $(86,110)$. Regardless of the scenario envisaged, plant developmental, paleobotanical, and molecular evidence suggests that "very ancient algal gene networks were co-opted during the evolution of the embryophytes multicellular body plan" (89), emphasizing the need to have a more thorough look into algal biology to understand fully land plant evolution. a Chlorophyta: green algae

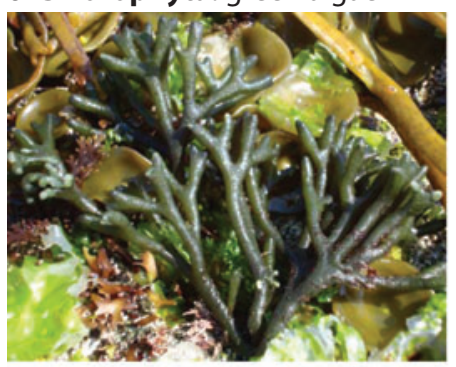

b Rhodophyta: red algae

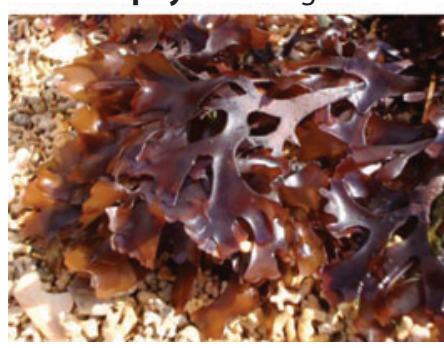

C Rhodophyta: red algae
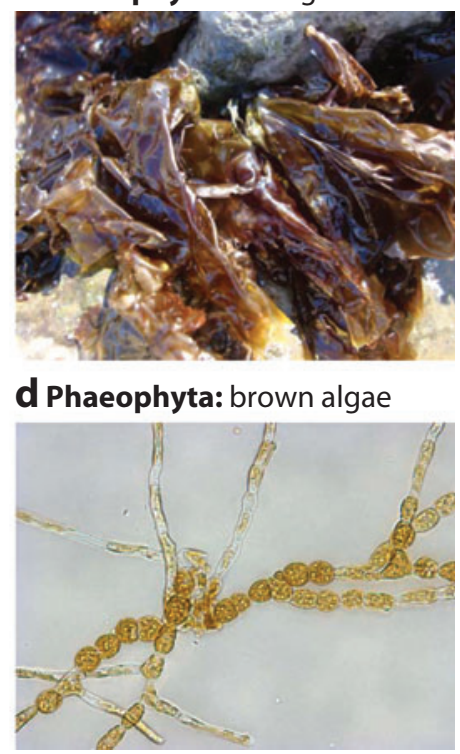

d Phaeophyta: brown algae

Figure 2

Representatives of the major lineages of marine multicellular algae: (a) Codium fragile, Chlorophyceae; (b) Chondrus crispus, Rhodophyta; (c) Porphyra

umbilicalis, Rhodophyta; and (d) Ectocarpus siliculosus, Phaeophyceae. Images in panels $a, b$, and $c$ provided by D.B. Stengel and image in panel $d$ by D. Scornet.
Multicellularity, in plants and algae, intrinsically involves the evolution of a cell wall or an extracellular matrix because the groups of cells that constitute a functional multicellular organism must be able to recognize, adhere to, and communicate with each other. The
Secondary

endosymbiosis: the uptake and retention of an existing plastidcontaining alga by a heterotrophic eukaryotic cell

\section{PENIUM MARGARITACEUM (ZYGNEMATOPHYTA) AS A MODEL ORGANISM}

Penium is rapidly emerging as a model organism, and several characteristics make it a particularly appropriate tool for investigating Streptophytina (including land plants) cell-wall biochemistry. To begin with, it is a unicellular organism in the CGA, and it produces only a primary cell wall. Additionally, it has a cell-wall polymer constituency similar to land plants. It also is amenable to live-cell labeling with monoclonal antibodies and carbohydratebinding modules for developmental studies. Finally, there is relative ease in its experimental manipulation, and genomic libraries will be available soon. 
Table 1 Major cell-wall polymers present in different plant and algal taxa

\begin{tabular}{|c|c|c|c|c|c|}
\hline \multirow[b]{2}{*}{ Polysaccharide } & \multicolumn{3}{|c|}{ Chloroplastida } & \multirow[b]{2}{*}{ Rhodophyta } & \multirow[b]{2}{*}{ Phaeophyceae } \\
\hline & Embryophyceae & Charophyceae & Chlorophyta & & \\
\hline $\begin{array}{l}\text { Crystalline } \\
\text { polysaccharides }\end{array}$ & Cellulose & Cellulose & Cellulose $^{132}$ & $\begin{array}{c}\text { Cellulose }^{93} \\
(1 \rightarrow 4)-\beta \text {-D-mannan } \\
(1 \rightarrow 4)-\beta \text {-D-xylan } \\
(1,57 \\
(1 \rightarrow 3)-\beta \text {-D-xylan } 24,57\end{array}$ & Cellulose $^{93}$ \\
\hline Hemicelluloses & $\begin{array}{l}\text { Xyloglucan }{ }^{101} \\
\text { Mannans }^{104} \\
\text { Xylans }^{17} \\
\text { MLG }^{93} \\
(1 \rightarrow 3)-\beta \text {-glucan }\end{array}$ & $\begin{array}{l}\text { Xyloglucan }{ }^{30} \\
\text { Mannans } \\
\text { Xylans } s^{30} \\
(1 \rightarrow 3) \text { - } \beta \text {-glucan }\end{array}$ & $\begin{array}{l}\text { Xyloglucan }{ }^{62,63} \\
\text { Mannans }^{93} \\
\text { Glucuronan } \\
(1 \rightarrow 3)-\beta \text {-glucan }\end{array}$ & $\begin{array}{c}\text { Glucomannan }{ }^{64} \\
\text { Sulfated MLG64 } \\
(1 \rightarrow 3),(1 \rightarrow 4)-\beta-D-x y l a n^{24,57,93}\end{array}$ & $\begin{array}{c}\text { Sulfated } \\
\text { xylofucoglucan } \\
\text { Sulfated } \\
\text { xylofucoglucuronan } \\
\text { (1, } \rightarrow 3) \text { - } \beta \text {-glucan }\end{array}$ \\
\hline $\begin{array}{l}\text { Matrix carboxylic } \\
\text { polysaccharides }\end{array}$ & Pectins & Pectins & Ulvans $s^{62}$ & - & Alginates $^{57}$ \\
\hline $\begin{array}{l}\text { Matrix sulfated } \\
\text { polysaccharides }\end{array}$ & - & - & Ulvans & $\begin{array}{c}\text { Agars }^{57,93} \\
\text { Carrageenans } \\
\text { Porphyran }\end{array}$ & Homofucans ${ }^{57,93}$ \\
\hline
\end{tabular}

Wall polymers are defined as follows: cellulose, $(1 \rightarrow 4)-\beta$-D-glucan; MLG, $(1 \rightarrow 3),(1 \rightarrow 4)$ - $\beta$-D-glucan; ulvans, sulfated xylorhamnoglucuronans. Agars, carrageenans, and porphyrans are sulfated $\alpha-(1 \rightarrow 3), \beta-(1 \rightarrow 4)$-galactans differentiated by the fact that agars and porphyrans contain D- and L-galactose, whereas carrageenans contain only D-galactose, and alginates are polymers of $\alpha$-L-guluronic acid and $\beta$-D-mannuronic acid. We recommend the following reviews, which cover this topic in greater depth $(24,57,93,103)$.

Chlorophyta: green algae including marine and freshwater, and micro- and macroalgae

Chloroplastida: a group comprising the land plants

(Embryophyceae), the CGA from which they emerged, and the Chlorophyta green algae predominantly found in marine habitats

Red algae

(Rhodophyta):

micro- and macroscopic algae predominantly present in marine environments that evolved through a primary endosymbiotic event $\sim 1.2$ billion years ago cell-wall/extracellular matrix plays crucial roles in the control of cell differentiation (development) and in innate immunity, two other common characteristics of multicellular Eukaryotes (12). Furthermore, "the endoskeleton-like infrastructure of cell walls resulting from multicellularity also mechanically reinforces the plant body against the effects of moving water or air" (86). The volvocine green algae provide an interesting example of a relatively recent ( $\sim 50 \mathrm{Mya})$ transition toward simple multicellularity, which involved both the expansion and the differentiation of extracellular matrix glycoproteins (56). The recent genomic comparison between the multicellular green alga Volvox carteri and its extant unicellular relative Chlamydomonas reinhardtii confirms that one of the most fundamental differences between these two algae is the expansion of the cell wall-specific gene families in $V$. carteri (104). The divergence of brown algae from unicellular diatoms is an example of a transition to complex multicellularity. The genomic analysis of the brown alga Ectocarpus siliculosus unravels the gain of a family of receptor kinases, which evolved independently from animal tyrosine and plant serine/threonine receptor kinases (20). Such an emergence of receptor kinases is thought to have been a key event in the evolution of animal and plant multicellularity (21). However, the expansion of cell wall-related genes also is observed, resulting in large multigenic families, such as cell-wall integrity and stress response component (WSC) domains and mannuronan C5-epimerases (83).

Cell-wall components also enable multicellularity as they are involved in adhering the cells that compose the organism. In land plants and the multicellular CGA, a pectin-rich portion of the cell wall known as the middle lamella is deposited during cell division and subsequently holds the daughter cells together. Pectin is not a unique component of multicellular CGA and land plants as it is also present in unicellular CGA, including Penium margaritaceum (Figure 5). A xyloglucan-like polysaccharide from a filamentous CGA, Spirogyra, has also been suggested to have a role in cell-cell attachment (50). There is also the potential that cell-wall components involved in cell-cell 
Table 2 The presence of CAZy family genes known to be involved in cell-wall metabolism in land plants and their distribution in sequenced members of brown algae, red algae, green algae, and land plants

\begin{tabular}{|c|c|c|c|c|c|c|c|c|c|}
\hline & GH16(XTH) & GT2 & GT8 & GT14 & GT43 & GT47 & GT48 & GT64 & GT75 \\
\hline \multicolumn{10}{|c|}{ Brown algae (complex multicellularity) } \\
\hline Ectocarpus siliculosus (82) & - & 9 & 3 & 5 & - & 8 & 3 & 2 & - \\
\hline \multicolumn{10}{|l|}{ Red microalgae } \\
\hline Cyanidioschyzon merolae $^{\mathrm{a}}$ (2) & - & - & 1 & - & - & - & - & 2 & - \\
\hline \multicolumn{10}{|l|}{ Green microalgae } \\
\hline Micromonas sp. RCC299 (141) & - & 6 & - & - & - & 3 & 2 & 1 & - \\
\hline Micromonas sp. CCMP1545 (141) & - & 6 & - & - & 1 & - & - & 1 & - \\
\hline Ostreococcus tauri (141) & - & 6 & - & - & - & - & 2 & 1 & - \\
\hline Chlamydomonas reinhardtii $^{\mathrm{b}}$ & - & - & - & - & - & 29 & 3 & 1 & 1 \\
\hline \multicolumn{10}{|c|}{ Green algae (simple multicellularity) } \\
\hline 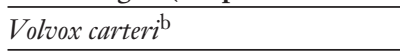 & - & - & - & - & - & 15 & 4 & 1 & 3 \\
\hline \multicolumn{10}{|l|}{ Embryophytes } \\
\hline Physcomitrella patens $(\mathrm{moss})^{\mathrm{b}}$ & 31 & 28 & 14 & 5 & 5 & 46 & 12 & 5 & 6 \\
\hline $\begin{array}{l}\text { Selaginella moellendorffii } \\
\text { (lycopod) }^{\mathrm{b}}\end{array}$ & 19 & 13 & 8 & 2 & 3 & 20 & 9 & 5 & 4 \\
\hline $\begin{array}{l}\text { Oryza sativa Japonica group } \\
\text { (monocot) (16) }\end{array}$ & 31 & 47 & 39 & 12 & 10 & 35 & 11 & 3 & 3 \\
\hline Arabidopis thaliana (dicot) (16) & 33 & 42 & 42 & 11 & 4 & 39 & 12 & 3 & 5 \\
\hline Populus trichocarpa (dicot) (40) & 41 & 74 & 61 & 14 & 7 & 75 & 18 & 4 & 11 \\
\hline
\end{tabular}

The census of the CAZymes, unless referenced, is based on Blast analysis on ${ }^{2}$ Cyanidioschyzon merolae Genome Web site (http://merolae.biol.s.u-tokyo. ac.jp/) or the ${ }^{\mathrm{b} J G I}$ Web site (http://genome.jgi-psf.org/).

attachment may share some characteristics with proteoglycan and carbohydrate constituents known to enable various algae to adhere to substrates $(28,32,140)$.

\section{Differentiation and Cell-Wall Diversity}

An important advantage of multicellularity is that it enables increased size and life span and allows some cells to differentiate (86). This can confer a survival advantage as multicellularity facilitates homeostasis; a longer-lived organism is likely to produce more progeny than its shorter-lived counterparts; attack by herbivores or pathogens may not obliterate the entire organism; and damaged cells can be isolated from the remaining healthy tissues (86). Furthermore, multicellularity enables some cells to differentiate, and there is evidence that differentiation is associated largely with diversifi- cation and the subsequent recruitment of cell wall-related proteins. For example, in addition to their role in cell-wall structure, the Volvox pherophorins have a novel role as a diffusible sex-inducer glycoprotein (104). Cell differentiation in plants exists at the level of cell-wall composition, with specific wall components being located within specific lineages $(38,39,45$, $84,101,102,123,131)$, tissues, or cells, or it can be regulated temporally or spatially within a single cell $(35,67)$. Similarly, cell-wall differentiation exists in macroalgae $(24,57)$, with differences in polysaccharide components depending on the species $(42,46,63,73)$, part of the alga (64), developmental and life-cycle stage (60), and season and habitat (57).

The inheritance of the machinery required to synthesize (and potentially modify) a specific cell-wall component is responsible primarily for whether a specific component can be present within a given lineage, with 


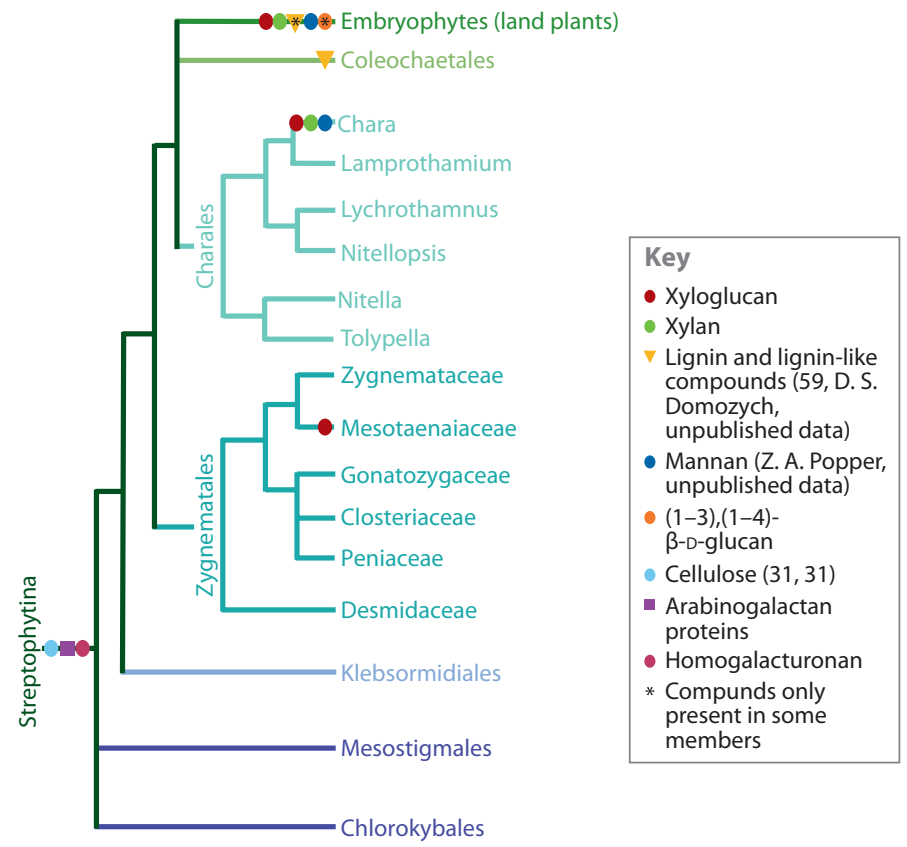

Figure 3

Phylogeny of the Streptophytina (133), showing the wall composition within the charophycean green algae. The identification of specific wall components within a lineage is symbolized as in the key.

regulatory networks controlling whether the component is synthesized, along with its temporal and spatial localization $(79,119)$. The existence of diversity in wall composition within a single plant can lead to difficulties when investigating cell-wall evolution. For example, xyloglucan was thought to be absent from the cell walls of charophytes (101), but monoclonal antibody labeling has since suggested its localization in Chara antheridia (30), and a xyloglucanlike polysaccharide has been reported to be involved in cell-cell attachment in Spirogyra (50). These findings complement the previous identification of a xyloglucan-like polysaccharide in the cell walls of a marine chlorophyte (62). Adequate sampling to include different cell types and different developmental stages as well as different taxa is therefore essential (123).

In addition, it can be difficult to ascertain whether a component is homologous when it is found in distantly related taxa with quite different body plans. For example, lignin is a phenolic polymer typically associated with the cell walls of vascular plants. Its emergence is assumed to have played a key role in the diversification of land plants by providing structural support, enabling plants to grow taller, enhancing light interception and thereby primary productivity, and facilitating development of a more efficient water-transport system. Lignins are classified as $\mathrm{H}-$, G-, or S-lignins, depending on the type of monolignol involved (138), with S-lignin found only in certain lineages, specifically the angiosperms and lycopods (53). However, the HGS-lignins have been reported recently to occur in developmentally specialized cell walls from the red alga Calliarthron cheilosporioides (78), which probably last shared a common ancestor with vascular plants over 1 billion years ago. This is a peculiar and potentially anomalous finding as lignin was believed to be present only in vascular plants. However, for this polymer to be considered truly homologous, it should not only be structurally identical but also be synthesized via the same biosynthetic pathway. Although the lignin biosynthesis pathway in Calliarthron has not been deduced, it is known that S-lignins in lycopods and angiosperms, which last shared a common ancestor $400 \mathrm{Mya}$, are synthesized by distinctly different biosynthetic pathways $(138,139)$ and are therefore the result of convergent evolution (103). In the particular case of the red alga in which all three types of lignin were found, a convergent evolution hypothesis would imply the concomitant innovation of all the pathways involved. This scenario is not the most parsimonious hypothesis. Therefore, an in-depth analysis of the lignin biosynthesis pathways in $C$. cheilosporioides is required to assess if this is a case of convergent evolution or ancestral inheritance.

Elucidation of the biochemical pathways and complete genomes is essential to comprehend plant and algal cell-wall evolution. Several sequencing projects have focused on land plants, including Arabidopsis (129), rice (51), poplar (134), Brachypodium (130), Selaginella (currently being sequenced by the Joint Genome Initiative, Department of Energy, United States), and Physcomitrella patens 

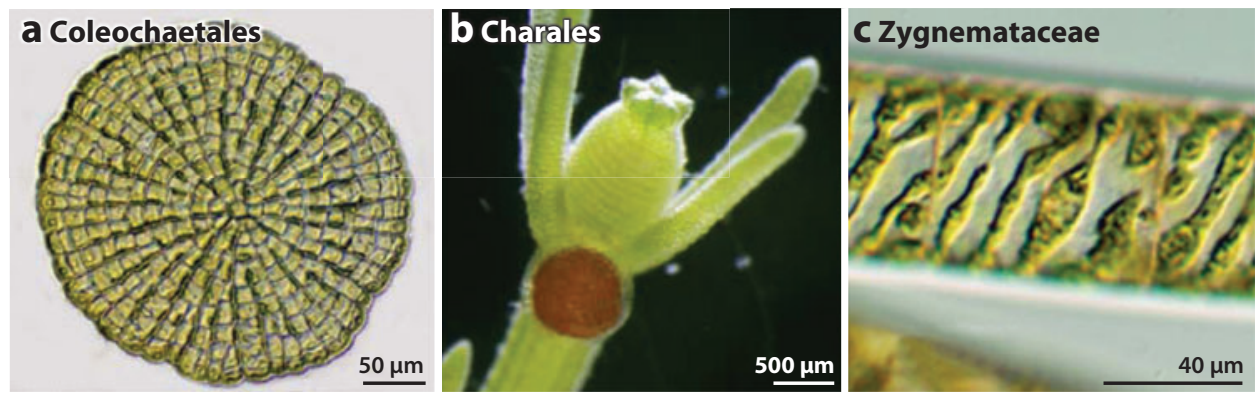

\section{d Mesotaenaiaceae}

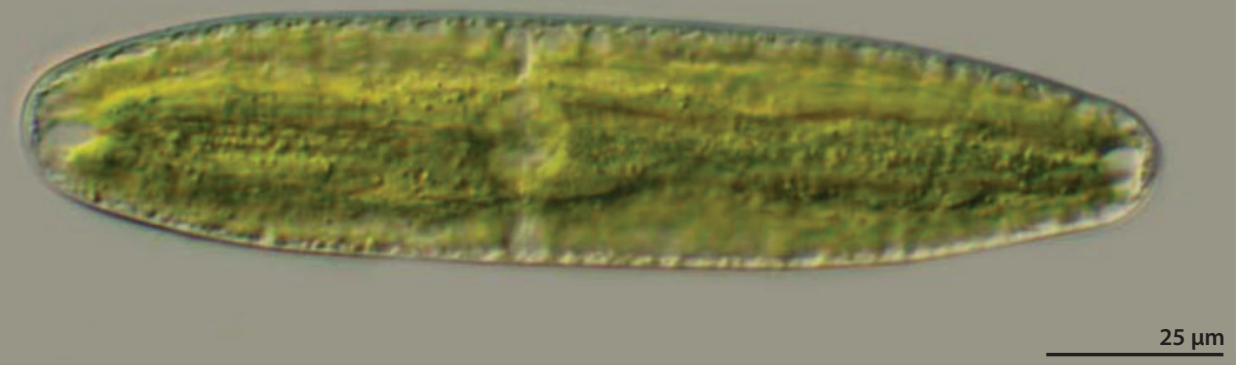

\section{e Peniaceae}
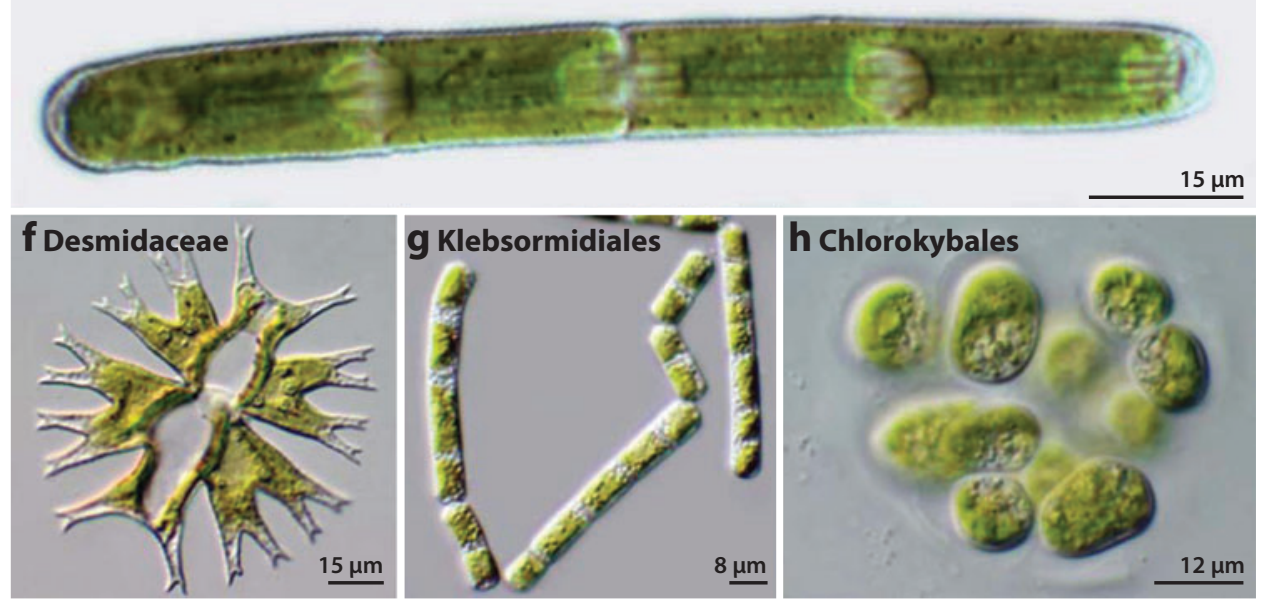

Figure 4

Representatives of the charophycean green algae, showing their diversity of shape and growth form (multicellular, unicellular, and colonial): (a) Coleochaete orbicularis, Coleochaetales; (b) Chara corallina, Charales; ( $c$ ) Spirogyra sp., Zygnemataceae; (d) Netrium digitus, Mesotaenaiaceae; (e) Penium margaritaceum, Peniaceae; $(f)$ Micrasterias furcata, Desmidaceae; $(g)$ Klebsormidium flaccidum, Klebsormidiales; and (b) Chlorokybus atmophyticus, Chlorokybales. Images provided by D.S. Domozych. 
a
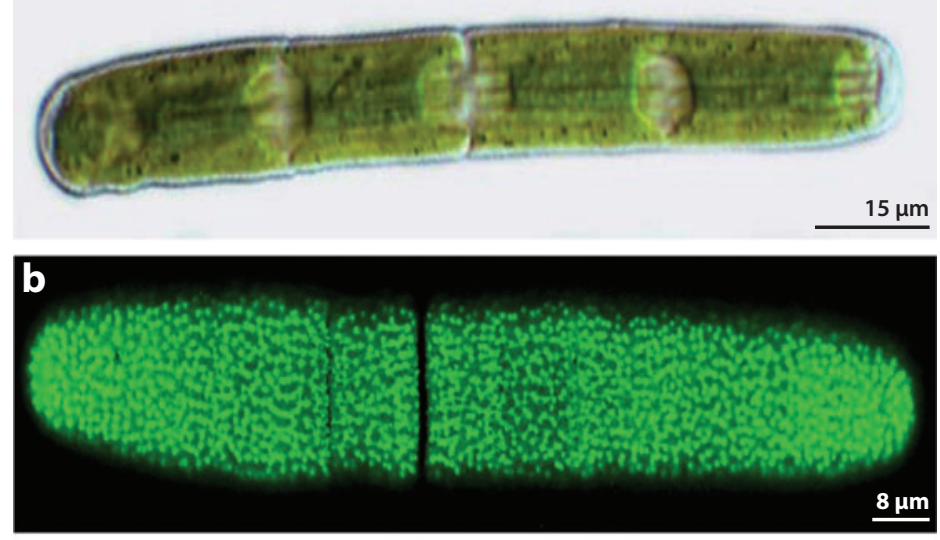

C

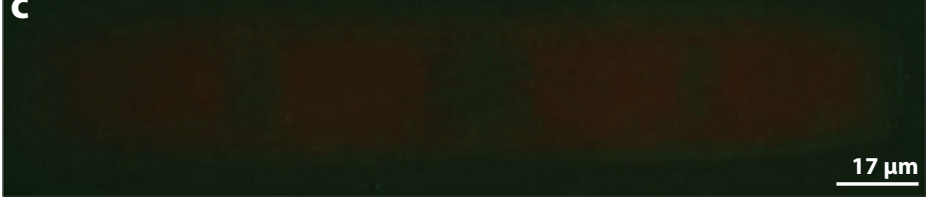

Figure 5

Penium margaritaceum (Peniaceae, Zygnematophyta) (a) under white light; (b) labeled with JIM5, a monoclonal antibody that recognizes epitopes present in homogalacturonans; and $(c)$ as a control for monoclonal antibody labeling in which the primary antibody was eliminated during labeling. Images courtesy of D.S. Domozych.

(111), whereas only a few have focused on algae. Furthermore, the majority of algal genomes that have been sequenced are unicellular: the red algae Cyanidioschyzon merolae and Galdieria sulfuraria (6); the green algae Ostreococcus (25), Chlamydomonas (80), and Micromonas (141); and the diatoms Thalassiosira (3) and Phaeodactylum (11). These microalgae have highly reduced or modified walls, and only limited information concerning cell-wall biosynthesis can be derived from their genomes. This situation has changed recently with the first publication of the genome of a multicellular green alga, $V$. carteri (104), and two members of the CGA (128). Together with the upcoming genome sequence of the unicellular CGA $P$. margaritaceum (Figure 5), these organisms will provide additional tools to elucidate cell-wall evolution in green plants.

GT:

glycosyltransferase release of the genome sequence from a brown seaweed, E. siliculosus (20; Figure 2), which represents an additional model for transition to complex multicellularity and the potential involvement of a cell wall. In addition, its endosymbiotic history with a red alga has provided the opportunity to investigate ancestral pathways shared between plants and algae, notably genes involved in carbohydrate metabolism (82, 83). Although a genome sequence from a multicellular red alga is still missing, further sequencing projects currently underway on the red macroalgae Porphyra umbilicalis (Joint Genome Institute, United States; http://www.jgi.doe.gov/sequencing/ why/99171.html), Porphyra yezoensis (Kazusa DNA Research Institute, Japan), and Chondrus crispus (Genoscope, France; http://www. sb-roscoff.fr/genomique-fonctionnellerecherche/364-le-projet-genome-dechondrus-crispus.html) should contribute toward filling the gap. Future analyses of these plant and algal genome sequences will facilitate greatly our ability to address the many questions relating to cell-wall evolution that are still pending.

The complex mechanisms involved in cellwall biosynthesis and metabolism are currently the foci of intense research but are not resolved fully, even in land plants. Nonetheless, the increasing amount of genomic data on plants and algae provides opportunities to determine which cell wall-related pathways are ancestral, lineage-specific, or inherited through horizontal or endosymbiotic gene transfers.

The polymerization of 1,3-glucans is catalyzed by family 48 glycosyltransferases (GT48) (16), which are absent in Bacteria and Archaea but conserved in most Eukaryotes, including fungi, plants (callose synthases), oomycetes, and brown algae. The GT48 phylogenetic tree is congruent with the currently accepted phylogeny of the Eukaryotes, indicating that the synthesis of $1,3-\beta$-glucans is a very ancient eukaryotic pathway (82). Other cellwall/extracellular matrix-related families of GTs (GT14, GT47, and GT64) are conserved between animals, plants, and brown algae and are thus thought to be ancestral (83). These

GT families are involved in the biosynthesis of 
sulfated glycosaminoglycans in animals (127), whereas they are mostly responsible for branching in pectins and xyloglucans in land plants $(52,74)$. The exact specificity of these GTs in brown algae is currently unknown. Family 8 glycosyltransferases (GT8) also are found in fungi, animals, plants (16), and brown algae (82). However, this GT family is polyspecific, and not all enzymes are involved in cellwall/extracellular matrix metabolism. In plants, the GAUT subfamily comprises galacturonosyltransferases required for homogalacturonan synthesis (143), but fungal and animal GT8s are involved in glycogen metabolism (72) and Notch receptor glycosylation (122). The brown alga Ectocarpus possesses three GT8s, one closely related to animal GT8, whereas the other GT8s cluster within the plant subfamily PGSIP-B (143). GT43 also constitutes an ancient eukaryotic protein family involved in the metabolism of the extracellular matrix, participating in glycosaminoglycan synthesis in animals (127) and glucuronoxylan elongation in land plants (65). This GT family is absent in Ectocarpus (82) and was probably lost during evolution of the brown algae. Conversely, animals and all marine algae, irrespective of their phylogenetic position, produce sulfated polysaccharides as major extracellular matrix components, whereas freshwater and land plants do not (see the section Aquatic Habitats below). Genomic comparison indicates that the syntheses of sulfated polysaccharides involve ancestral pathways conserved at least between brown algae and animals. In contrast, key enzymes, sulfatases and carbohydrate sulfotransferases are completely absent from plant genomes (83; see the section Terrestrialization below for further details).

Perhaps the most well-understood wall biosynthetic machinery is the family of cellulose synthase genes (CesA, family GT2), implicated in cellulose biosynthesis, which, similar to cellulose, are widespread among Eukaryotes and Prokaryotes (115, 116, 132). However, cellulose synthesis is not an ancestral eukaryotic pathway in land plants. Molecular evidence indicates that plants acquired cellulose synthases from Cyanobacteria (90). The sequence of the recently characterized cellulose synthase from the red alga $P$. yezoensis also clustered with cyanobacterial CesA (116), confirming that cellulose synthase(s) was acquired during primary endosymbiosis at the base of the Archaeplastida supergroup. In the Ces As phylogenetic tree, the cellulose synthases from oomycetes and brown algae cluster close to the cyanobacterial and red algal sequences, suggesting that Stramenopiles acquired the capacity to produce cellulose from their rhodobionts (83). The molecular evidence is consistent with differences in the structural organization of cellulose synthase terminal complexes found between brown, red, and green algae and the CGA and land plants (132). Cellulose synthases likely were lost by diatoms, after the divergence from brown algae.

Many land-plant cell-wall components are synthesized by genes that resulted from diversification of Ces $A$ s to cellulose synthase-like $(C s l)$ gene families $(68,144)$. Although seven to eight $C s l$ genes are encountered in seed plants, only three are found in mosses $(\operatorname{Csl}[A C D J)$ and only one, a unique gene most homologous to $C s l A$ and $C s l C$, is found in green algae (144). This would imply the possible duplication of the common ancestor of CslA and $C s l C$ in land plants subsequent to their divergence from green algae. In land plants, $C s l A$ and $C s l C$ have been reported to be involved in mannan and xyloglucan synthesis, respectively (68). Thus, because mannan is present in the cell walls of green algae, Yin et al. (144) suggested that the ancestral $C s l[A C]$ gene might have been a mannan synthase. As multicellular red algae also are known to contain mannan and glucomannan (24, 64; Table 1), it would be interesting to know if they additionally contain a gene with high sequence homology to Csl[AC]. Such diversification of the CesA family is not observed in Ectocarpus, although this brown alga possesses a second Csl subfamily of actinobacterial origin (83). Therefore, the expansion and diversification of the CesA family appears to be trait specific to the Embryophytes, possibly related to terrestrialization. 
MLG: mixed-linkage glucan, $(1 \rightarrow 3),(1 \rightarrow 4)$ $\beta$-D-glucan

GH: glycosylhydrolase

Horizontal gene transfer: the transfer of genes across normal mating barriers
The functional role of the Csl[BDEG] families remains unclear, but the Csl[FHF] genes have been shown to be involved in MLG synthesis in grasses $(14,15,27,113)$. MLG was thought previously to be restricted to the cell walls of the Poales (131) and was seen as a substantial innovation of this taxon. However, it now has been reported to occur in fungi $(13,98)$, brown algae (103), red algae (64), green algae (33), and horsetails (Equisetum spp.) $(39,124)$. Because all these taxa, with the exception of the Poales, existed prior to the divergence of Csl[FH7], this lends support for multiple origins of the polymer (13) but adds uncertainty to elucidating the mechanism by which MLG is synthesized in these groups. The existence of a sulfated MLG in red algae (64) suggests that wall components likely can be modified differentially depending on the presence of co-occurring biosynthetic genes, which may be regulated environmentally (see the section Aquatic Habitats below).

The origin of some cell-wall components and of their biosynthetic enzymes remains unclear. For instance, xyloglucan endohydrolase (XEH) and xyloglucan endotransglucosylase (XET) are homologous enzymes involved in xyloglucan metabolism. XEH hydrolyzes the xyloglucan backbone, whereas XET carries out interpolymeric grafting between two xyloglucan molecules. XET and XEH both belong to the large polyspecific family GH16 (5), which notably encompasses the laminarinases, lichenases, $\beta$-agarases, $\mathrm{k}$-carrageenases, and the recently discovered $\beta$-porphyranases (46). Structural and phylogenetic analyses demonstrated that XET diverged later from an ancestral glycosylhydrolase (GH) (81). Similarly XEH has been shown to have evolved secondarily from an ancestral XET (8). Interestingly, an enzyme has been isolated recently from Equisetum and charophytic algae that has MLG:xyloglucan endotransglucosylase (MXE) activity and grafts MLG to xyloglucan (38). The existence of MXE activity in charophytes is intriguing because it was thought that $\mathrm{xy}$ loglucan was lacking from their cell walls (101). Immunocytochemistry since has suggested that xyloglucan is localized to the antheridia in Chara (30), so MXE may be involved in expansive growth of these cells. MXE activity has been suggested as a primordial feature of plant cell walls (38). To confirm such a hypothesis, one would need to clone the gene corresponding to this novel activity. An enticing speculation is that MXE could be a new member of family GH16 and would share a close common ancestor with XET. The subsequent steps to test Fry and coworkers' (38) hypothesis would be to confirm the presence of an MXE gene in the CGA and to compare the sequence between different CGA members. However, although $P$. margaritaceum (Figure 5) is being sequenced currently, only a few members of the CGA have been sequenced fully and annotated to date (128).

Besides the divergence of ancestral genes and the transfer of genes during major endosymbiotic events, the evolution of algal and plant cell walls also is likely to have been influenced by horizontal gene transfer in specific lineages. This is clearly the case in the green alga Micromonas, which surprisingly possesses several genes involved in the biosynthesis of bacterial peptidoglycan (141). Analysis of the Ectocarpus genome also found that significant horizontal gene transfer probably occurred with an actinobacterium, leading to the de novo acquisition of an additional pathway for carbon storage, based on mannitol (82). This horizontal gene transfer also provided several crucial cell-wall polysaccharides, alginates, and some hemicellulose-like polymers produced by a new subfamily of GT2. This horizontal gene transfer event was a turning point in the evolution of brown algae toward the acquisition of complex multicellularity (83).

The comparison of the numbers of genes within each GH and GT family from sequenced plants and algae provides additional insight into the evolution and diversification of cell wallrelated polysaccharides. The available genomes of unicellular red and green algae suggest that they are significantly poorer in cell wallrelated genes than flowering plants $(82,83$; see Table 2). This is not unexpected as these 
microalgae feature reduced or highly modified cell walls. Ectocarpus has a total of $41 \mathrm{GHs}$ and 88 GTs (82), with fewer members per family than Arabidopsis (which has $730 \mathrm{GH}$ and GTs) (48). However, this multicellular brown alga shares many cell wall-related families with plants (GT2, GT8, GT14, GT47, GT48, and GT64). A notable difference is the lack of GT43 and of XET/XEH (GH16), which can be explained by the apparent absence of xyloglucan in brown algae.

With the exception of the GT47 family in mosses, moss and lycopod genomes have smaller GT family sizes (16) (Table 2). However, although Selaginella has a smaller XET/XEH family than do Arabidopsis and rice, the number of members in Physcomitrella is comparable directly with that in rice (Table 2). This could reflect loss within the lycopod lineage, but it also could suggest that XET/XEH family members may have some different roles in the moss. The flowering plants Arabidopsis and rice have comparable numbers of genes in each family, with the exception of the GT43 family for which there are more members present in rice (Table 2). GT43 is involved in the synthesis of the xylan backbone of hemicelluloses. The increased GT43 family size in rice most likely correlates with the known existence of a greater concentration of (glucuronoarabino)xylan with a high degree of structural complexity in grass cell walls (137). By contrast, the poplar genome contains 1.6 times more CAZymes than does Arabidopsis, with most families increased proportionally, although xylan- and pectin-related families are underrepresented. However, profound changes occur in the CAZyme transcriptomes, with regulation being related to tissue type (40). As another example of gene family size, $P$. patens has been shown to contain only two of the four expansin families usually found in angiosperms (18). However, this is balanced by an increased number and divergence of the genes from the extant families in the moss, which would imply that it is a functional advantage for the plant to maintain large multigenic families. Interestingly, no expansin homologs are found in
Ectocarpus, suggesting that different mechanisms of cell-wall remodeling exist in brown algae (83). Altogether, the emergence of the Streptophytes appears to be associated with an expansion and diversification of cell wallrelated genes $(103,144)$.

\section{Cell-Cell Communication}

Multicellularity requires the ability of intercellular communication, and plants and green, red, and brown algae have developed at least two methods to enable cell-cell communication networks. First, specialized pores within the cell wall known as plasmodesmata have evolved independently in several lineages, including the land plants, CGA, and some members of the green and brown algae (108). They enable the movement of molecules, potentially including those involved in signaling, across adjoining cell walls. Second, these organisms may use molecules that can diffuse across, or are located within, the cell wall as signaling molecules; these may be relatively unspecialized chemicals such as nutrients or highly specialized molecules. Arabinogalactan proteins represent a hugely diverse group of wall components that may act as soluble signals (121) and have been demonstrated to have a widespread occurrence in plants and algae $(28,33,66,103)$.

\section{Unicellularity}

Unicellularity may exist as part of the life cycle of a multicellular plant or alga. For example, motile (or nonmotile) gametes and asexual spores (e.g. zoospores, aplanospores) represent specialized differentiated unicells derived from multicellular thalli. However, currently it is thought that the majority of taxa within the Eukaryotes are actually unicellular organisms (4). Surprisingly, even unicellular algae whose wall composition is extremely modified or reduced may provide new insight into the evolution of the wall. For example, C. merolae, an essentially wall-less red alga, contains genes involved in the extracellular matrix (6). The green alga Ostreococcus, also wall-less, 
contains a gene related to $C s l A$ and $C s l C$ designated $C s l A / C s l C$ (144), which has products that may be involved in cell-surface glycosylation to help protect the alga from grazers (94). These observations suggest that some wall components may have evolved initially to fulfill a role that was not involved primarily in cell-wall structure and that the genes involved in their synthesis were later co-opted and diversified for participation in cell-wall biosynthesis. The same is true for individual sugar residues of specific wall polymers. For example, rhamnogalacturonan II (RGII) has a highly conserved structure and is present in all vascular plants (79) but has not been detected in green algae (31). However, RGII contains some highly unusual sugar residues, including 3-deoxy-D-manno-2octulosonic acid (Kdo) (145), which is found also in the scales or theca of the Prasinophyceae (31). Furthermore, the sequence for CMP-Kdo synthetase required for generating the activated sugar donor needed for synthesis of wall polymers containing Kdo has been found in land plants as well as in gram-negative Eubacteria (117). The genes required for biosynthesis therefore appear to have ancient origins although the polymer is likely to be an innovation of the land plants potentially resulting from the selection pressures experienced during terrestrialization.

\section{TERRESTRIALIZATION, VASCULARIZATION, AND DIVERSIFICATION}

\section{Aquatic Habitats}

Terrestrialization, and the subsequent taxonomic proliferation of land plants, was predated by a divergence between the Chlorophyte and the Streptophyte lineages. This is correlated strongly with a change in habitat preference from saline to freshwater (10). These transitions are accompanied by a major alteration in cell wall-polysaccharide composition such that, although the majority of marine Chlorophytes contain sulfated cell-wall polysaccharides (63,
106), they are largely absent from the freshwater GCA and their descendants (Table 1).

Interestingly, sulfated carbohydrate polymers are widespread in nature, occurring in a great variety of organisms: in the cell walls of marine angiosperms; in marine green, red, and brown algae (Table 1); in the extracellular matrix of vertebrate tissues; and in invertebrate species (2). As such, the terrestrial and freshwater plants, which are not known to contain sulfated polysaccharides, or genes involved in sulfation of such polymers are more the exception than the rule. Although the ability to produce sulfated cell-wall polysaccharides might have been lost in freshwater and land plants, marine angiosperms such as Zostera marina are believed to have regained this ability as a result of a physiological adaptation to their secondary exploitation of marine habitats (75). There is strong evidence that the occurrence of sulfated polysaccharides in phylogenetically distant taxa is a case of convergent adaptation to highly ionic environments (seawater for marine plants and algae and physiological saline serum for vertebrate tissues).

Sulfated wall polysaccharides from marine plants and algae may confer an adaptive advantage through possible structural and osmotic functions that are correlated with an environmental pressure. Analysis of the Ectocarpus genome led Michel et al. (83) to suggest that, similar to metazoan glycosaminoglycans (127), sulfated fucans may be polymerized as neutral polysaccharides and then subsequently modified by specific sulfotransferases and sulfatases. Several candidate genes with homology to known carbohydrate sulfotransferases were found in Ectocarpus that most likely enable sulfation at different positions on the fucan backbone (83). The fucan could be remodeled further by the action of sulfatases, of which nine were found to be present in the Ectocarpus genome (83). As many as 16 sulfatases also have been found in Chlamydomonas (80), and this increased number of sulfatases could represent a diversity of substrate specificities, potentially including sulfated MLG. 
Although further evidence is required, early emerging freshwater and terrestrial organisms may have had a demand for sulfur that was in excess of that available in terrestrial and freshwater habitats (109), such that the requirement for sulfate may have become a limiting factor and therefore may have selected against organisms in a terrestrial environment, potentially resulting in the lack of carbohydrate sulfotransferases and sulfatases from the genomes of freshwater algae and land plants and sulfated polysaccharides from their cell walls (83).

\section{Terrestrialization}

Although the precise phylogeny of the CGA is still disputed (Figure 3), there is relative consensus that land plants compose a monophyletic group of photosynthetic organisms that diverged from within the CGA 430-470 Mya (55). This was a pivotal event in the history of the tree of life and of the Earth as colonization of the land by green multicellular plants not only led to their own diversification, but also enabled the existence of terrestrial animals and altered the Earth's geology and climate (88). However, to colonize successfully the terrestrial habitat, the ancestors of land plants had to evolve effective strategies to cope with a relatively inhospitable environment in which they faced several constraints.

Some of the most immediate constraints to a successful terrestrial existence are not related specifically to the cell wall and include gas diffusion, dehydration, osmotic stress, and nitrogen availability. However, some cell wall characteristics may have facilitated survival on land. Multicellularity, although only secondarily involving the cell wall, is thought to confer some desiccation tolerance (86).

By allowing for increased size, multicellularity and differentiation help reduce the rate of desiccation (86), but they also bring about the requirement for long-distance transport. A unicellular photoautotroph carries out photosynthesis and respiration in the same cell, and cytoplasmic streaming and diffusion are adequate to meet metabolic needs. These same mechanisms also would suffice in terrestrial multicellular organisms but limit greatly the attainable size, particularly in potentially desiccating terrestrial habitats, such that even early diverging land plants, including many bryophytes, have some conducting tissues (the hydrome and leptome) $(86,110)$. However, a more elaborate mechanism designed for longdistance transport is present in the vascular plants, and an analogous system exists in several complex brown algae, including Macrocystis (70, 96), Laminaria (34), and members of the Fucales (26), which are related only distantly to recently sequenced Ectocarpus. This system facilitates the movement of photosynthate (mannitol in the brown algae, and sucrose and other sugars in vascular plants) from source to sink. In vascular plants, water is also transported, in this case from the roots to the lamina. The capability of long-distance transport therefore has arisen independently at least twice within photosynthetic Eukaryotes. Additionally, although they are not homologous, these Eukaryotes share some distinct characteristics for long-distance transport $(70,71)$. For example, the specialized transport cells or trumpet hyphae of the Laminariales appear to develop by controlled digestion of the end walls of specific cells (142); this is also the case for the xylem and phloem of vascular plants. Vascular plants subsequently deposit wall components such as lignin within their vascular tissues. However, this is likely to have evolved as a strengthening mechanism, enabling upright growth in a terrestrial environment. Interestingly, the sieve plates in plants and Laminariales are made of 1,3- $\beta$-glucans (71). Even though the sieve elements have evolved independently in plants and brown algae, their biogenesis likely involved 1,3- $\beta$ glucan synthases, which are ancestral GT48s (82).

A terrestrial existence also subjected plants and algae to increased ultraviolet (UV) radiation; water attenuates some UV radiation and enables some behavioral responses, such as movement within the water column (109). 
Streptophytina: subdivision comprising the classes

Charophyceae (CGA) and Embryophyceae (land plants)
UV radiation can lead to DNA damage as well as reduced primary productivity and survival rates. It thus might be expected that it would be advantageous for land plants to develop UV screening mechanisms. Lignin-like phenolic compounds are deposited in the cell walls of a variety of the CGA and are thought to protect against desiccation (59), making them prime candidates for such a role, thus potentially exhibiting a dual function. Similarly, marine macroalgae accumulate photoprotective phenolic compounds such as mycosporinelike amino acids (derived via the shikimate pathway) and phlorotannins (synthesized from the acetate-melonate pathway) in their walls in response to UV exposure (120). Both the shikimate and acetate-melonate pathways are present in land plants (112), making it plausible that the earliest diverging land plants could employ (and extend) a pre-existing strategy for coping with high UV light.

Phlorotannins are produced by polymerization of phloroglucinol and are known only from brown algae; in addition to UV protection, they have a role in discouraging grazing (135) and inhibit enzyme activity and potentially digestion (7). Tannins present in vascular plants (102) have similar properties, and their occurrence in vascular plants correlates with expanded numbers of mammalian grazers (105).

The ability of vascular plants to synthesize and deposit phenolic compounds within cell walls (in this case, lignins) also played a role in providing more strength, which increased the attainable height and improved water transport efficiency. This would have given the plants a competitive advantage by supporting greater primary productivity and reduced shading, enabling the capture of more incident light energy while facilitating higher water transport rates. In aquatic environments, macroalgal thalli are supported by buoyancy and have less of a requirement for additional strengthening to enable increased upright growth; microalgae and colonial or filamentous algae simply move within the water column. This makes the discovery of lignin in a red alga, as discussed above, all the more intriguing (78).

\section{Innate Immunity}

Cell-wall integrity sensing is a trait, shared between land plants and algae, which enables the effective activation of the host defense mechanisms during pathogen ingress. Cell-wall fragments can elicit signals leading to a defense response. In land plants, the oligogalacturonic acids are the best-characterized wall-derived elicitors $(47,114)$. Examples of the perception of endogenous oligosaccharides also are known from red and brown macroalgae $(23,61)$. Although signal perception and relay are poorly understood in macroalgae compared with in land plants, some basic signaling mechanisms appear to be conserved (23). Additional wall sensors have been described from land plants, including the pectin-binding wall-associated kinases (58). Plasma membrane-bound cell surface sensors known as WSCs characterized from yeast (22) have no apparent homologs in land plants. However, they have been found in the Ectocarpus genome, in which they are likely to bind algal polysaccharides (20). These similarities raise questions regarding the origin and evolution of cell-wall involvement in innate immunity in Eukaryotes.

\section{CONCLUSIONS AND KEY PROBLEMS}

Some variation in algal wall composition (57) appears to have taxonomic relevance; an $r b c L-$ based phylogeny of the Rhodophyta clustered those families that synthesize typical carrageenans in their cell walls in a monophyletic group (36). However, based on evidence currently available, it is virtually impossible to ascertain how algal cell walls may have changed during the evolution of the many different taxa. There are several reasons for this. First, the extant photosynthetic marine organisms are hugely diverse at the higher taxonomic levels (107). This means that there is greater morphological, biochemical, and genetic variation between individual marine photosynthetic taxa than there is within the taxa that make up the Streptophytina (CGA and land plants) (107). 
Second, there is a lack of genome-level analysis of the marine photosynthetic organisms, with few algal genomes sequenced and annotated and insufficient characterization of wall biochemistry. However, more significantly, their phylogenies are not well resolved, particularly within the Rhodophyta (36), making it highly speculative to relate known differences, in morphology and biochemistry, between different taxa to any specific evolutionary scenarios. Further complicating the picture is that much of the variation seen in algal wall composition is highly dependent on habitat, season, and lifecycle stage. For example, the green alga Acetabularia has mannan-rich cell walls, but the walls of its cysts are rich in cellulose (71). Consequently, although cell-wall biochemistry could enrich our understanding of algal evolution, it is currently at an extremely preliminary stage, and extensive research is required to elucidate the relationship between wall composition and evolution in algae.

The evolutionary relationships within algae contrast with those in the CGA and land plants, which form a monophyletic group. The members of this group have a high degree of similarity in their overall wall composition (30, $101,123)$, but subtle changes in wall chemistry, such as structural diversity within specific wall components, or changes in their proportional contribution to wall composition, occur that have phylogenetic consistency $(99,123)$ : for example, the occurrence of novel uronic acid-containing side chains in bryophytes, equisetophytes, and lycopodiophytes (97) and the presence of 3-O-methylrhamnose in place of the nonreducing rhamnose residue on the aceric acid-containing side chain of RGII in some lycopodiophytes and pteridophytes (79). In addition, there are some tissue-specific alterations that are linked to growth habit, such as deposition of lignin in the secondary cell walls of vascular plants.

It is likely that in the future evolutionary inferences may be made regarding plant and algal wall composition that may deepen our understanding of the evolution of these organisms. However, this will require more resolved eukaryotic phylogenies as well as more detailed knowledge regarding the wall composition and biosynthesis in a far broader range of plants and algae.

\section{SUMMARY POINTS}

1. Most photosynthetic multicellular Eukaryotes, including land plants and algae, have a carbohydrate-rich cell wall.

2. Variation and diversity in the cell-wall composition of the monophyletic group consisting of the CGA and land plants are cell, tissue, temporally, and species specific.

3. Key changes in cell-wall composition can be mapped onto a phylogeny of the CGA and land plants, and they appear to have accompanied major evolutionary events such as terrestrialization and vascularization.

4. Algae have walls that have a composition that is markedly different from the CGA and land plants although the complex relationships between land plants and algae explain some shared cell-wall components. However, the current available information regarding eukaryotic algal phylogenies, algal cell-wall compositions, and the machinery employed in algal cell-wall biosynthesis precludes conclusive hypotheses to be drawn with respect to the evolution of cell walls at lower taxonomic ranks (e.g. species) known to occur within algal lineages.

5. Algal cell walls, similar to land plants, exhibit variation in cell-wall composition dependent on the part of the thallus, developmental stage, and season, which results from regulation of cell-wall biosynthesis rather than the presence or absence of specific genes. 


\section{FUTURE ISSUES}

1. Structural and biochemical constituents of cell-wall components from an increased diversity of plant and algal cell walls need to be characterized.

2. Genes involved in the synthesis of a greater number of cell-wall components should be identified, along with their distribution among living organisms.

3. The function of wall-related genes should be elucidated.

4. Mechanisms of wall metabolism and interactions between wall components need to be understood more fully.

5. Cell-, tissue-, species- and temporally specific localizations of wall components should be investigated in vivo.

6. The regulation of cell-wall-specific genes needs to be elucidated more fully.

\section{DISCLOSURE STATEMENT}

The authors are not aware of any affiliations, memberships, funding, or financial holdings that might be perceived as affecting the objectivity of this review.

\section{ACKNOWLEDGMENTS}

We thank Delphine Scornet, Station Biologique de Roscoff, for the E. siliculosus image and Dr. Solène Connan, NUI Galway, for useful comments on the manuscript. D.S.D. received financial support from National Science Foundation grants NSF-MCB-0919925 and NSF-IOS-0848071.

\section{LITERATURE CITED}

1. Adl SM, Simpson AGB, Farmer MA, Andersen RA, Anderson OR, et al. 2005. A new higher level classification of eukaryotes with emphasis on the taxonomy of protists. F. Eukaryot. Microbiol. 52:399-451

2. Aquino RS, Landeira-Fernandez AM, Valente AP, Andrade LR, Mourão PA. 2005. Occurrence of sulfated galactans in marine angiosperms: evolutionary implications. Glycobiology 15:11-20

3. Armbrust EV, Berges JA, Bowler C, Green BR, Martinez D, et al. 2004. The genome of the diatom Thalassiosira pseudonana: ecology, evolution, and metabolism. Science 306:79-86

4. Baldauf SL. 2008. An overview of the phylogeny and diversity of eukaryotes. F. Syst. Evol. 46:263-73

5. Barbeyron T, Gerard A, Potin P, Henrissat B, Kloareg B. 1998. The K-carrageenase of the marine bacterium Cytophaga drobachiensis: structural and phylogenetic relationships within family-16 glycoside hydrolases. Mol. Biol. Evol. 15:528-37

6. Barbier G, Oesterhelt C, Larson MD, Halgren RG, Wilkerson C, et al. 2005. Comparative genomics of two closely related unicellular thermo-acidophilic red algae, Galdieria sulphuraria and Cyanidioschyzon merolae, reveals the molecular basis of Galdieria sulphuraria and significant differences in carbohydrate metabolism of both algae. Plant Physiol. 137:460-74

7. Barwell CJ, Blunden G, Manandhar PD. 1989. Isolation and characterization of brown algal polyphenols as inhibitors of $\alpha$-amylase, lipase and trypsin. 7. Appl. Phycol. 1:319-23

8. Baumann MJ, Eklöf JM, Michel G, Kallas AM, Teeri TT, et al. 2007. Structural evidence for the evolution of xyloglucanase activity from XETs: biological implications for cell wall metabolism. Plant Cell 19:1947-63

9. Baurain D, Brinkman H, Petersen J, Rodríguez-Ezpeleta N, Stechmann A, et al. 2010. Phylogenomic evidence for separate acquisition of plastids in cryptophytes, haptophytes, and stramenopiles. Mol. Biol. Evol. 27:1698-709 
10. Becker B, Marin B. 2009. Streptophyte algae and the evolution of the embryophytes. Ann. Bot. 103:9991004

11. Bowler C, Allen AE, Badger JH, Grimwood J, Jabbari K, et al. 2008. The Phaeodactylum genome reveals the evolutionary history of diatom genomes. Nature 456:239-44

12. Brownlee C. 2002. Role of the extracellular matrix in cell-cell signaling: paracrine paradigms. Curr. Opin. Plant Biol. 5:396-401

13. Burton RA, Fincher GB. 2009. (1,3;1,4)- $\beta$-D-Glucans in the cell walls of the Poaceae, lower plants, and fungi: a tale of two linkages. Mol. Plant 2:873-82

14. Burton RA, Jobling SA, Harvey AJ, Shirley NJ, Mather DE, et al. 2008. The genetics and transcriptional profiles of the cellulose synthase-like HvCslF gene family in barley (Hordeum vulgare L.). Plant Physiol. 146:1821-33

15. Burton RA, Wilson SM, Hrmova M, Harvey AJ, Shirley NJ, et al. 2006. Cellulose synthase-like CslF genes mediate the synthesis of cell wall $(1,3 ; 1,4)-\beta$-D-glucans. Science. $311: 1940-42$

16. Cantarel BL, Coutinho PM, Rancurel C, Bernard T, Lombard V, et al. 2009. The Carbohydrate-Active EnZymes database (CAZy): an expert resource for glycogenomics. Nucleic Acids Res. 37:D233-38

17. Carafa A, Duckett JG, Knox JP, Ligrone R. 2005. Distribution of cell-wall xylans in bryophytes and tracheophytes: new insights into basal inter-relationships in land plants. New Phytol. 168:231-40

18. Carey RE, Cosgrove DJ. 2007. Portrait of the expansin superfamily in Physcomitrella patens: comparisons with angiosperm expansins. Ann. Bot. 99:1131-41

19. Cavalier-Smith T. 1999. Principles of protein and lipid targeting in secondary symbiogenesis: euglenoid, dinoflagellate, and sporozoan plastid origins and the eukaryote family tree. F. Eukaryot. Microbiol. 46:34766

20. Cock JM, Sterk L, Rouzé P, Scornet D, Allen AE, et al. 2010. The Ectocarpus genome and the independent evolution of multicellularity in brown algae. Nature 465:617-21

21. Cock JM, Van Oosthuyse V, Gaude T. 2002. Receptor kinase signaling in plants and animals: distinct molecular systems with mechanistic similarities. Curr. Opin. Cell Biol. 14:230-36

22. Cohen-Kupiec R, Broglie KE, Friesem D, Broglie RM, Chet I. 1999. Molecular characterization of a novel $\beta$-1,3-exoglucanase related to the mycoparasitism of Trichoderma harzianum. Gene 226:147-54

23. Cosse A, Leblanc C, Potin P. 2007. Dynamic defense of marine macroalgae against pathogens: from early activated to gene-regulated responses. Adv. Bot. Res. 46:221-66

24. Craigie JS. 1990. Cell walls. In Biology of the Red Algae, ed. KM Cole, RG Sheath, pp. 221-57. Cambridge, UK: Cambridge Univ. Press

25. Derelle E, Ferraz C, Rombauts S, Rouzé P, Worden AZ, et al. 2006. Genome analysis of the smallest freeliving eukaryote Ostreococcus tauri unveils many unique features. Proc. Natl. Acad. Sci. USA 103:11647-52

26. Diouris M, Floc'h JY. 1984. Long-distance transport of ${ }^{14} \mathrm{C}$-labelled assimilates in the Fucales: directionality, pathway and velocity. Mar. Biol. 78:199-204

27. Doblin MS, Pettolino FA, Wilson SM, Campbell R, Burton RA, et al. 2009. A barley cellulose synthase-like CSLH gene mediates (1,3;1,4)- $\beta$-D-glucan synthesis in transgenic Arabidopsis. Proc. Natl. Acad. Sci. USA 14:5996-6001

28. Domozych DS, Elliot L, Kiemle SN, Gretz MR. 2007. Pleurotaenium trabecula, a desmid of wetland biofilms: the extracellular matrix and adhesion mechanisms. F. Phycol. 43:1022-31

29. Domozych DS, Serfis A, Kiemle SN, Gretz MR. 2007. The structure and biochemistry of charophycean cell walls. I. Pectins of Penium margaritaceum. Protoplasma 230:99-115

30. Domozych DS, Sørensen I, Willats WGT. 2009. The distribution of cell wall polymers during antheridium development and spermatogenesis in the charophycean green alga, Chara corallina. Ann. Bot. 104:1045-56

31. Domozych DS, Wells B, Shaw PJ. 1991. The basket scales of the green alga Mesostigma viridae: chemistry, immunology and ultrastructure. 7. Cell. Sci. 100:397-407

32. Eder M, Lütz-Meindl U. 2009. Analyses and localization of pectin-like carbohydrates in cell wall and mucilage of the green alga Netrium digitus. Protoplasma 230:99-115

33. Eder M, Tenhaken R, Driouich A, Lütz-Meindl U. 2008. Occurrence and characterization of arabinogalactan-like proteins and hemicelluloses in Micrasterias (Streptophyta). F. Phycol. 44:1221-34
20. First publication of a multicellular seaweed genome providing insights into the evolution of multicellular complexity. 
34. Floc'h JY, Penot M. 1976. Étude comparative du transport à longue distance de différents radioéléments dans le thalle de Laminaria digitata (Linné) Lamouroux. C. R. Acad. Sci. D 282:989-92

35. Freshour G, Clay RP, Fuller MS, Albersheim P, Darvill AG, et al. 1996. Developmental and tissuespecific structural alterations of the cell-wall polysaccharides of Arabidopsis thaliana roots. Plant Physiol. 110:1413-29

36. Freshwater DW, Fredericq S, Butler BS, Hommersand MH, Chase MW. 1994. A gene phylogeny of the red algae (Rhodophyta) based on plastid rbcL. Proc. Natl. Acad. Sci. USA 91:7281-85

37. Fry SC. 2000. The Growing Plant Cell Wall: Chemical and Metabolic Analysis. Caldwell, NJ: Blackburn. Reprint ed.

38. Fry SC, Mohler KE, Nesselrode BHWA, Franková L. 2008. Mixed-linkage $\beta$-glucan: xyloglucan endotransglucosylase, a novel wall-remodeling enzyme from Equisetum (horsetails) and charophytic algae. Plant 7. 55:240-52

39. Fry SC, Nesselrode BH, Miller JG, Mewburn BR. 2008. Mixed-linkage $(1 \rightarrow 3,1 \rightarrow 4)$ - $\beta$-D-glucan is a major hemicellulose of Equisetum (horsetail) cell walls. New Phytol. 179:104-15

40. Geisler-Lee J, Geisler M, Coutinho PM, Segerman B, Nishikubo N, et al. 2006. Poplar carbohydrateactive enzymes: gene identification and expression analyses. Plant Physiol. 140:946-62

41. Grosberg RK, Strathmann RR. 2007. The evolution of multicellularity: a minor major transition? Annu. Rev. Ecol. Evol. Syst. 38:621-54

42. Guibet M, Boulenguer P, Mazoyer J, Kervarec N, Antonopoulos A, et al. 2008. Composition and distribution of carrabiose moieties in hybrid K-/ l-carrageenans using carrageenases. Biomacromolecules 9:408-15

43. Hampl V, Hug L, Leigh JW, Dacks JB, Lang BF, et al. 2009. Phylogenomic analyses support the monophyly of the Excavata and resolve relationships among eukaryotic "supergroups." Proc. Natl. Acad. Sci. USA 106:3859-64

44. Harris D, Bulone V, Ding S-Y, Debolt S. 2010. Tools for cellulose analysis in plant cell walls. Plant Pbysiol. 153:420-26

45. Harris PJ, Hartley RD. 1976. Detection of bound ferulic acid in the cell walls of the gramineae by ultraviolet fluorescence microscopy. Nature 259:508-10

46. Hehemann J-H, Correc G, Barbeyron T, Helbert W, Czjzek M, et al. 2010. Transfer of carbohydrateactive enzymes from marine bacteria to Japanese gut microbionta. Nature 464:908-12

47. Hématy K, Cherk C, Somerville S. 2009. Host-pathogen warfare at the plant cell wall. Curr. Opin. Plant Biol. 12:406-13

48. First complete consensus of carbohydrate active enzymes in a plant genome.

\section{Highly} recommended review detailing the cell-wall polysaccharides of macroalgae.
48. Henrissat B, Coutinho PM, Davies GJ. 2001. A consensus of carbohydrate-active enzymes in the genome of Arabidopsis thaliana. Plant Mol. Biol. 47:55-72

49. Hervé C, Marcus SE, Knox JP. 2011. Monoclonal antibodies, carbohydrate-binding modules and the detection of polysaccharides in plant cell walls. In The Plant Cell Wall: Methods and Protocols, ed. Popper ZA. Methods in Molecular Biology, 715:103-13. New York: Springer Sci./Bus. Media.

50. Ikegaya H, Hayashi T, Kaku T, Iwata K, Sonobe S, et al. 2008. Presence of xyloglucan-like polysaccharide in Spirogyra and possible involvement in cell-cell attachment. Pbycol. Res. 56:216-22

51. Int. Rice Seq. Proj. 2005. The map-based sequence of the rice genome. Nature 436:793-800

52. Iwai H, Masaoka N, Ishii T, Satoh S. 2002. A pectin glucuronosyltransferase gene is essential for intercellular attachment in the plant meristem. Proc. Natl. Acad. Sci. USA 10:15843-45

53. Jin ZF, Matsumoto Y, Tange T, Akiyama T, Higuchi M, et al. 2005. Proof of the presence of guaiacylsyringyl lignin in Selaginella tamariscina. 7. Wood Sci. 51:424-26

54. Keeling PJ. 2010. The endosymbiotic origin, diversification and fate of plastids. Philos. Trans. R. Soc. Lond. B 365:729-48

55. Kenrick P, Crane P. 1997. The origin and early evolution of plants on land. Nature 389:33-39

56. Kirk DL. 2005. A twelve-step program for evolving multicellularity and division of labor. BioEssays 27:299-310

57. Kloareg B, Quatrano RS. 1988. Structure of the cell walls of marine algae and ecophysiological functions of the matrix polysaccharides. Oceanogr. Mar. Biol. Annu. Rev. 26:259-315

58. Kohorn BD, Kobayashi M, Johansen S, Riese J, Huang LF, et al. 2006. An Arabidopsis cell wall-associated kinase required for invertase activity and cell growth. Plant 7. 46:307-16 
59. Kroken SB, Graham LE, Cook ME. 1996. Occurrence and evolutionary significance of resistant cell walls in the charophytes and bryophytes. Am. 7. Bot. 83:1241-54

60. Kropf DL, Kloareg B, Quatrano RS. 1988. Cell wall is required for fixation of the embryonic axis in Fucus zygotes. Science 239:187-90

61. Küpper FC, Kloareg B, Guern J, Potin P. 2001. Oligoguluronates elicit an oxidative burst in the brown algal kelp Laminaria digitata. Plant Physiol. 125:278-91

62. Lahaye M, Jegou D, Buléon A. 1994. Chemical characteristics of insoluble glucans from the cell wall of the marine green alga Ulva lactuca (L.) Thuret. Carbobydr. Res. 262:115-25

63. Lahaye M, Robic A. 2007. Structure and functional properties of ulvan, a polysaccharide from green seaweeds. Biomacromolecules 8:1765-74

64. Lechat H, Amat M, Mazoyer J, Buléon A, Lahaye M. 2000. Structure and distribution of glucomannan and sulfated glucan in the cell walls of the red alga Kappaphycus alvarezii (Gigartiales, Rhodophyta). $\mathcal{F}$. Pbycol. 36:891-902

65. Lee CH, Teng Q, Huang W, Zhong R, Ye ZH. 2010. The Arabidopsis family GT43 glycosyltransferases form two functionally non-redundant groups essential for the elongation of glucuronoxylan backbone. Plant Physiol. 153:526-41

66. Lee KJD, Sakata Y, Mau SL, Pettolino F, Bacic A, et al. 2005. Arabinogalactan proteins are required for apical cell extension in the moss Physcomitrella patens. Plant Cell 17:3051-65

67. Leroux O, Knox JP, Leroux F, Vrijdaghs A, Bellefroid E, et al. 2007. Intercellular pectic protuberances in Asplenium: new data on their composition and origin. Ann. Bot. 100:1165-73

68. Lerouxel O, Cavalier DM, Liepman AH, Keegstra K. 2006. Biosynthesis of plant cell wall polysaccharides: a complex process. Curr. Opin. Plant Biol. 9:621-30

69. Lewis LA, McCourt RM. 2004. Green algae and the origin of land plants. Am. 7. Bot. 91:1535-56

70. Lobban CS. 1978. Translocation of ${ }^{14} \mathrm{C}$ in Macrocystis pyrifera (giant kelp). Plant Physiol. 61:585-89

71. Lobban CS, Harrison PJ. 1997. Seaweed Ecology and Physiology. Cambridge, UK: Cambridge Univ. Press

72. Lomako J, Lomako WM, Whelan WJ. 2004. Glycogenin: the primer for mammalian and yeast glycogen synthesis. Biochim. Biophys. Acta 1673:45-55

73. Mabeau S, Kloareg B. 1987. Isolation and analysis of the cell walls of brown algae: Fucus spiralis, F. ceranoides, F. vesiculosus, F. serratus, Bifurcaria bifurcata and Laminaria digitata. F. Exp. Bot. 38:1573-80

74. Madson M, Dunand C, Li X, Verma R, Vanzin GF. 2003. The MUR3 gene of Arabidopsis encodes a xyloglucan galactosyltransferase that is evolutionarily related to animal exostosins. Plant Cell 15:1662-70

75. Maeda M, Koshikawa M, Nisizawa K, Takano K. 1966. Cell wall constituents, especially pectic substance of a marine phanerogam Zostera marina. Bot. Mag. 79:422-26

76. Marcus SE, Verhertbruggen Y, Hervé C, Ordaz-Ortiz JJ, Farkas V, et al. 2008. Pectic homogalacturonan masks abundant sets of xyloglucan epitopes in plant cell walls. BMC Plant Biol. 8:60

77. Martin W, Rujan T, Richly E, Hansen A, Cornelsen S, et al. 2002. Evolutionary analysis of Arabidopsis, cyanobacterial and chloroplast genomes reveals plastid phylogeny and thousands of cyanobacterial genes in the nucleus. Proc. Natl. Acad. Sci. USA 99:12246-51

78. Martone PT, Estevez JM, Lu F, Ruel K, Denny MW, et al. 2009. Discovery of lignin in seaweed reveals convergent evolution of cell wall architecture. Curr. Biol. 19:169-75

79. Matsunaga T, Ishii T, Matsumoto S, Higuchi M, Darvill A, et al. 2004. Occurrence of the primary cell wall polysaccharide rhamnogalacturonan II in pteridophytes, lycophytes, and bryophytes: implications for the evolution of vascular plants. Plant Physiol. 134:339-51

80. Merchant SS, Prochnik SE, Vallon O, Harris EH, Karpowicz SJ, et al. 2007. The Chlamydomonas genome reveals the evolution of key animal and plant functions. Science 318:245-50

81. Michel G, Chantalat L, Duee E, Barbeyron T, Henrissat B, et al. 2001. The K-carrageenase of $P$. carrageenovora features a tunnel-shaped active site: a novel insight in the evolution of Clan-B glycoside hydrolases. Structure 9:513-25

82. Michel G, Tonon T, Scornet D, Cock JM, Kloareg B. 2010. Central and storage carbon metabolism of the brown alga Ectocarpus siliculosus: insights into the origin and evolution of the storage carbohydrates in Eukaryotes. New Phytol. 188:67-81 
83. Detailed annotation of cell-wall polysaccharide synthesis in a brown seaweed and insights into their evolutionary origins.

84. Description of a mAb-based method enabling rapid analysis of cell walls from multiple origins.

\section{Highly}

recommended review detailing the evolution of cell-wall components, specifically cellulose, in plants and algae.

104. First publication of a multicellular green algal genome, providing new insight into the mechanisms of multicellularity.
83. Michel G, Tonon T, Scornet D, Cock JM, Kloareg B. 2010. The cell wall polysaccharide metabolism of the brown alga Ectocarpus siliculosus: insights into the evolution of the extracellular matrix polysaccharides in Eukaryotes. New Phytol. 188:82-97

84. Moller I, Sørensen I, Bernal AJ, Blaukopf C, Lee K, et al. 2007. High-throughput mapping of cell wall polymers within and between plants using novel microarrays. Plant f. 50:1118-28

85. Mouille G, Robin S, Lecomte M, Pagent S, Höfte H. 2003. Classification and identification of Arabidopsis cell wall mutants using Fourier-transform infrared (FT-IR) microspectroscopy. Plant 7. 35:393-404

86. Niklas KJ. 1997. The Evolutionary Biology of Plants. Chicago: Univ. Chicago Press

87. Niklas KJ. 2000. The evolution of plant body plans: a biomechanical perspective. Ann. Bot. 85:411-38

88. Niklas KJ. 2004. The cell walls that bind the tree of life. BioScience 54:831-41

89. Niklas KJ, Kutschera U. 2010. The evolution of the land plant life cycle. New Phytol. 185:27-41

90. Nobels DR, Brown RM. 2004. The pivotal role of cyanobacteria in the evolution of cellulose synthases and cellulose synthase-like proteins. Cellulose 11:437-48

91. Obel N, Erben V, Pauly M. 2006. Functional wall genomics through oligosaccharide mass profiling. In The Science and Lore of the Plant Cell Wall: Biosynthesis, Structure and Function, ed. T Hayashi, pp. 258-66. Boca Raton, FL: Brown-Walker

92. Otegui MS, Mastronarde DN, Kang BH, Bednarek KY, Staehelin LA. 2001. Three-dimensional analysis of syncytial type cell wall plates during endosperm cellularization visualized by high resolution electron tomography. Plant Cell 13:2033-51

93. Painter TJ. 1983. Algal polysaccharides. In The Polysaccharides, ed. GO Aspinall, 2:195-285. New York: Academic

94. Palenik B, Grimwood J, Aerts A, Rouzé P, Salamov A, et al. 2007. The tiny eukaryote Ostreococcus provides genomic insights into the paradox of plankton speciation. Proc. Natl. Acad. Sci. USA 104:7705-10

95. Palmer JD, Soltis JE, Chase MW. 2004. The plant tree of life: an overview and some points of view. Am. 7. Bot. $91: 1437-45$

96. Parker BC, Huber J. 1965. Translocation in Macrocystis. II. Fine structure of the sieve tubes. F. Phycol. 1:172-79

97. Peña MJ, Darvill AG, Eberhard S, York WS, O'Neill MA. 2008. Moss and liverwort xyloglucans contain galacturonic acid and are structurally distinct from xyloglucans synthesized by hornworts and vascular plants. Glycobiology 18:891-904

98. Pettolino F, Sasaki I, Turbic A, Wilson SM, Bacic A, et al. 2009. Hyphal cell walls from the plant pathogen Rhynchosporium secalis contain $(1,3 ; 1,6)$ - $\beta$-D-glucans, galacto- and rhamnomannans, $(1,3 ; 1,4)$ $\beta$-D-glucans and chitin. FEBS 7. 276:4122-33

99. Popper ZA. 2008. Evolution and diversity of green plant cell walls. Curr. Opin. Plant Biol. 11:286-92

100. Popper ZA. 2011. The Plant Cell Wall: Methods and Protocols, ed. Popper ZA. Methods in Molecular Biology, 715. New York: Springer Sci./Bus. Media.

101. Popper ZA, Fry SC. 2003. Primary cell wall composition of bryophytes and charophytes. Ann. Bot. 91:1-12

102. Popper ZA, Fry SC. 2004. Primary cell wall composition of the pteridophytes and spermatophytes. New Phytol. 164:165-74

103. Popper ZA, Tuohy MG. 2010. Beyond the green: understanding the evolutionary puzzle of plant and algal cell walls. Plant Physiol. 153:373-83

104. Prochnik SE, Umen J, Nedelcu AM, Hallmann A, Miller SM, et al. 2010. Genomic analysis of organismal complexity in the multicellular green alga Volvox carteri. Science 329:223-26

105. Pryer KM, Schneider H, Smith AR, Cranfil R, Wolf PG, et al. 2001. Horsetails and ferns are a monophyletic group and the closest living relatives to seed plants. Nature 409:618-22

106. Quemener B, Lahaye M, Bobin-Dubigeon C. 1997. Sugar determination in ulvans by a chemical-enzymic method coupled to high performance anion exchange chromatography. 7. Appl. Phycol. 9:179-88

107. Raven JA. 1995. The early evolution of land plants: aquatic ancestors and atmospheric interactions. Bot. 7. Scotl. 47:151-75

108. Raven JA. 1997. Multiple origins of plasmodesmata. Eur. F. Phycol. 32:95-101

109. Raven JA. 1997. The role of marine biota in the evolution of terrestrial biota: gases and genes. Biogeochemistry 39:139-64 
110. Raven JA. 1999. The size of cells and organisms in relation to the evolution of embryophytes. Plant Biol. $1: 2-12$

111. Rensing SA, Lang D, Zimmer AD, Terry A, Salamov A, et al. 2008. The Physcomitrella genome reveals evolutionary insights into the conquest of land by plants. Science 319:64-69

112. Richards TA, Dacks JB, Campbell SA, Blanchard JL, Foster PG. 2006. Evolutionary origins of the eukaryotic shikimate pathway: gene fusions, horizontal gene transfer, and endosymbiotic replacements. Eukaryot. Cell 5:1517-31

113. Richmond T, Somerville C. 2000. The cellulose synthase superfamily. Plant Physiol. 124:495-98

114. Ridley BL, O’Neill MA, Mohnen D. 2001. Pectins: structure, biosynthesis, and oligogalacturoniderelated signaling. Phytochemistry 57:929-67

115. Roberts AW, Roberts E, Delmer DP. 2002. Cellulose synthase (CesA) genes in the green alga Mesotaenium caldariorum. Eukaryot. Cell 1:847-55

116. Roberts E, Roberts AW. 2009. Cellulose synthase (CesA) genes in the red alga Porphyra yezoensis Ueda. 7. Phycol. 45:203-12

117. Royo J, Gómez E, Hueros G. 2000. CMP-KDO synthetase: a plant gene borrowed from gram-negative eubacteria. Trends Genet. 16:432-33

118. Sarkar P, Bosneaga E, Auer M. 2009. Plant cell walls throughout evolution: towards a molecular understanding of their design principals. F. Exp. Bot. 60:3615-35

119. Schiefelbein J, Kwak S-H, Wieckowski Y, Barron C, Bruex A. 2009. The gene regulatory network for root epidermal cell-type pattern formation in Arabidopsis. F. Exp. Bot. 60:1515-21

120. Schoenwaelder MEA, Clayton MN. 1999. The presence of phenolic compounds in isolated cell walls of brown algae. Phycologia 38:161-66

121. Seifert GJ, Roberts K. 2007. The biology of arabinogalactan proteins. Annu. Rev. Plant Biol. 58:137-61

122. Sethi MK, Buettner FF, Krylov VB, Takeuchi H, Nifantiev NE. 2010. Identification of glycosyltransferase 8 family members as xylosyltransferases acting on $O$-glucosylated notch epidermal growth factor repeats. 7. Biol. Chem. 285:1582-86

123. Sørensen I, Domozych D, Willats WGT. 2010. How have plant cell walls evolved? Plant Physiol. 153:366-72

124. Sørensen I, Pettolino FA, Wilson SM, Doblin MS, Johansen B, et al. 2008. Mixed-linkage $(1 \rightarrow 3),(1 \rightarrow 4)$ $\beta$-D-glucan is not unique to the Poales but is an abundant component of Equisetum arvense cell walls. Plant 7. 54:510-21

125. Stebbins GL. 1992. Comparative aspects of plant morphogenesis: a cellular, molecular and evolutionary approach. Am. 7. Bot. 79:589-98

126. Stiller JW, Huang J, Ding Q, Tan J, Goodwillie C. 2009. Are algal genes in non-photosynthetic protists evidence of historical plastid endosymbioses? BMC Genomics 10:484

127. Sugahara K, Kitagawa H. 2002. Heparin and heparan sulfate biosynthesis. IUBMB Life 54:163-75

128. Timme RE, Delwiche CF. 2010. Uncovering the evolutionary origin of plant molecular processes: comparison of Coleochaete (Coleochaetales) and Spirogyra (Zygnematales) transcriptomes. BMC Plant Biol. 10:96

129. Arabidopsis Genome Initiat. 2000. Analysis of the genome sequence of the flowering plant Arabidopsis thaliana. Nature 408:796-815

130. Int. Brachypodium Initiat. 2010. Genome sequencing and analysis of the model grass Brachypodium distachyon. Nature 463:763-68

131. Trethewey JAK, Campbell LM, Harris PJ. 2005. $(1 \rightarrow 3),(1 \rightarrow 4)-\beta-D-G l u c a n s$ in the cell walls of the Poales (sensu lato): an immunogold labeling study using a monoclonal antibody. Am. F. Bot. 92:1669-83

132. Tsekos I. 1999. The sites of cellulose synthesis in algae: diversity and evolution of cellulose-synthesising enzyme complexes. 7. Phycol. 35:635-55

133. Turmel M, Otis C, Lemieux C. 2007. An unexpectedly large and loosely packed mitochondrial genome in the charophycean green alga Chlorokybus atmophyticus. BMC Genomics 8:137

134. Tuskan GA, Di Fazio S, Jansson S, Bohlmann J, Grigoriev I. 2006. The genome of black cottonwood, Populus trichocarpa (Torr. \& Gray). Science 313:1596-604
123. Comprehensive review discussing the evolution of land plant cell walls. 
135. Van Alstyne KL, Whitman SL, Ehlig JM. 2001. Differences in herbivore preferences, phlorotannin production, and nutritional quality between juvenile and adult tissues from marine brown algae. Mar. Biol. 139:201-10

136. Van Sandt VST, Stiperaere H, Guisez Y, Verbelen JP, Vissenberg K. 2007. XET activity is found near sites of growth and cell elongation in bryophytes and some green algae: new insights into the evolution of primary cell wall elongation. Ann. Bot. 99:39-51

137. Verbruggen MA, Spronk BA, Schols HA, Beldman G, Voragen AGJ, et al. 1998. Structures of enzymically derived oligosaccharides from Sorghum glucuronoarabinoxylan. Carbohydr. Res. 306:265-74

138. Weng JK, Akiyama T, Bonawitz ND, Li X, Ralph J, et al. 2010. Convergent evolution of syringyl lignin biosynthesis via distinct pathways in the lycophyte Selaginella and flowering plants. Plant Cell 22:1033-45

139. Weng JK, Li X, Stout J, Chapple C. 2008. Independent origins of syringyl lignin in vascular plants. Proc. Natl. Acad. Sci. USA 105:7887-92

140. Wetherbee R, Lind JL, Burke J. 1998. The first kiss: establishment and control of initial adhesion by raphid diatoms. F. Phycol. 34:9-15

141. Worden AZ, Lee J-H, Mock T, Rouzé P, Simmons MP, et al. 2009. Green evolution and dynamic adaptations revealed by genomes of the marine picoeukaryote Micromonas. Science 324:268-72

142. Yamanouchi S. 1908. Sieve tubes in Laminariales. Bot. Gaz. 46:153-54

143. Yin Y, Chen H, Hahn MG, Mohnen D, et al. 2010. Evolution and function of the plant cell wall synthesis-related glycosyltransferase family 8. Plant Physiol. 153:1729-46

144. Yin Y, Huang J, Xu Y. 2009. The cellulose synthase superfamily in fully sequenced plants and algae. BMC Plant Biol. 9:99

145. York WS, Darvill AG, McNeil M, Albersheim P. 1985. 3-Deoxy-D-manno-2-octulosonic acid (KDO) is a component of rhamnogalacturonan II, a pectic polysaccharide in the primary cell walls of plants. Carbobydr. Res. 138:109-26

\section{RELATED RESOURCES}

Fry SC. 1995. Polysaccharide-modifying enzymes in the plant cell wall. Annu. Rev. Plant Biol. 46:497-520

Hayashi T. 1989. Xyloglucans in the primary cell wall. Annu. Rev. Plant Physiol. Plant Mol. Biol. 40:139-68

O’Neill MA, Ishii T, Albersheim P, Darvill AG. 2004. Rhamnogalacturonan II: structure and function of a borate cross-linked cell wall pectic polysaccharide. Annu. Rev. Plant Biol. 55:10939

Scheller HV, Ulvskov P. 2010. Hemicelluloses. Annu. Rev. Plant Biol. 61:263-89

Takahashi H, Kopriva S, Giordano M, Saito K, Hell R. 2011. Sulfur assimilation in photosynthetic organisms: molecular functions and regulators of transporters and assimilatory enzymes. Annu. Rev. Plant Biol. 62:157-84 


\section{Contents}

Volume 62, 2011

It Is a Long Way to GM Agriculture

Marc Van Montagu ...............................................................

Anion Channels/Transporters in Plants: From Molecular Bases to

Regulatory Networks

Hélène Barbier-Brygoo, Alexis De Angeli, Sophie Filleur, Fean-Marie Frachisse,

Franco Gambale, Sébastien Thomine, and Stefanie Wege

Connecting the Plastid: Transporters of the Plastid Envelope and

Their Role in Linking Plastidial with Cytosolic Metabolism

Andreas P.M. Weber and Nicole Linka....

Organization and Regulation of Mitochondrial Respiration in Plants

A. Harvey Millar, Fames Whelan, Kathleen L. Soole, and David A. Day

Folate Biosynthesis, Turnover, and Transport in Plants

Andrew D. Hanson and Fesse F. Gregory III

Plant Nucleotide Sugar Formation, Interconversion, and Salvage

by Sugar Recycling

Maor Bar-Peled and Malcolm A. O'Neill

Sulfur Assimilation in Photosynthetic Organisms: Molecular Functions

and Regulations of Transporters and Assimilatory Enzymes

Hideki Takahasbi, Stanislav Kopriva, Mario Giordano, Kazuki Saito, and Rüdiger Hell

Signaling Network in Sensing Phosphate Availability in Plants

Tzyy-fen Chiou and Sbu-I Lin

Integration of Nitrogen and Potassium Signaling Yi-Fang Tsay, Cheng-Hsun Ho, Hui-Yu Chen, and Shan-Hua Lin

Roles of Arbuscular Mycorrhizas in Plant Nutrition and Growth:

New Paradigms from Cellular to Ecosystem Scales

Sally E. Smith and F. Andrew Smith 
The BioCassava Plus Program: Biofortification of Cassava for

Sub-Saharan Africa

Richard Sayre, Fohn R. Beeching, Edgar B. Cahoon, Chiedozie Egesi, Claude Fauquet, Jobn Fellman, Martin Fregene, Wilhelm Gruissem, Sally Mallowa, Mark Manary, Bussie Maziya-Dixon, Ada Mbanaso, Daniel P. Schachtman, Dimuth Siritunga,

Nigel Taylor, Herve Vanderschuren, and Peng Zhang

In Vivo Imaging of $\mathrm{Ca}^{2+}, \mathrm{pH}$, and Reactive Oxygen Species Using

Fluorescent Probes in Plants

Sarah 7. Swanson, Won-Gyu Choi, Alexandra Chanoca, and Simon Gilroy ....

The Cullen-RING Ubiquitin-Protein Ligases

Zbibua Hua and Richard D. Vierstra ....

The Cryptochromes: Blue Light Photoreceptors in Plants and Animals

Inês Chaves, Richard Pokorny, Martin Byrdin, Nathalie Hoang, Thorsten Ritz,

Klaus Brettel, Lars-Oliver Essen, Gijsbertus T.7. van der Horst,

Alfred Batschauer, and Margaret Abmad

The Role of Mechanical Forces in Plant Morphogenesis

Vincent Mirabet, Pradeep Das, Arezki Boudaoud, and Olivier Hamant

Determination of Symmetric and Asymmetric Division Planes

in Plant Cells

Carolyn G. Rasmussen, Fobn A. Humphries, and Laurie G. Smith

The Epigenome and Plant Development

Guangming He, Axel A. Elling, and Xing Wang Deng ....

Genetic Regulation of Sporopollenin Synthesis and Pollen

Exine Development

Tobru Ariizumi and Kinya Toriyama

Germline Specification and Function in Plants

Frédéric Berger and David Twell.

Sex Chromosomes in Land Plants

Ray Ming, Abdelhafid Bendabmane, and Susanne S. Renner

Evolution of Photosynthesis

Martin F. Hobmann-Marriott and Robert E. Blankenship

Convergent Evolution in Plant Specialized Metabolism

Eran Pichersky and Efraim Lewinsohn

Evolution and Diversity of Plant Cell Walls: From Algae

to Flowering Plants

Zö̈ Popper, Gurvan Michel, Cécile Hervé, David S. Domozych,

William G.T. Willats, Maria G. Tuoby, Bernard Kloareg,

and Dagmar B. Stengel 